\title{
Dust emission size distribution impact on aerosol budget and radiative forcing over the Mediterranean region: a regional climate model approach
}

\author{
P. Nabat ${ }^{1}$, F. Solmon ${ }^{2}$, M. Mallet ${ }^{3}$, J. F. Kok ${ }^{4}$, and S. Somot ${ }^{1}$ \\ ${ }^{1}$ CNRM-GAME - URA1357, Météo-France, Centre National de Recherches Météorologiques, 42 avenue G. Coriolis, \\ 31057 Toulouse cedex 1, France \\ ${ }^{2}$ The Abdus Salam International Center for Theroretical Physics, Strada Costiera 11, 34100 Trieste, Italy \\ ${ }^{3}$ Laboratoire d'Aérologie, 16 avenue Édouard Belin, 31400 Toulouse, France \\ ${ }^{4}$ Advanced Study Program, National Center for Atmospheric Research, Boulder, CO, USA
}

Correspondence to: P. Nabat (pierre.nabat@meteo.fr)

Received: 30 April 2012 - Published in Atmos. Chem. Phys. Discuss.: 19 July 2012

Revised: 5 October 2012 - Accepted: 10 October 2012 - Published: 12 November 2012

\begin{abstract}
The present study investigates the dust emission and load over the Mediterranean basin using the coupled chemistry-aerosol-regional climate model RegCM-4. The first step of this work focuses on dust particle emission size distribution modeling. We compare a parameterization in which the emission is based on the individual kinetic energy of the aggregates striking the surface to a recent parameterization based on an analogy with the fragmentation of brittle materials. The main difference between the two dust schemes concerns the mass proportion of fine aerosol that is reduced in the case of the new dust parameterization, with consequences for optical properties. At the episodic scale, comparisons between RegCM-4 simulations, satellite and groundbased data show a clear improvement using the new dust distribution in terms of aerosol optical depth (AOD) values and geographic gradients. These results are confirmed at the seasonal scale for the investigated year 2008. This change of dust distribution has sensitive impacts on the simulated regional dust budget, notably dry dust deposition and the regional direct aerosol radiative forcing over the Mediterranean basin. In particular, we find that the new size distribution produces a higher dust deposition flux, and smaller top of atmosphere (TOA) dust radiative cooling. A multi-annual simulation is finally carried out using the new dust distribution over the period 2000-2009. The average SW radiative forcing over the Mediterranean Sea reaches $-13.6 \mathrm{~W} \mathrm{~m}^{-2}$ at the surface, and $-5.5 \mathrm{~W} \mathrm{~m}^{-2}$ at TOA. The $\mathrm{LW}$ radiative forcing
\end{abstract}

is positive over the basin: $1.7 \mathrm{~W} \mathrm{~m}^{-2}$ on average over the Mediterranean Sea at the surface, and $0.6 \mathrm{~W} \mathrm{~m}^{-2}$ at TOA.

\section{Introduction}

Atmospheric aerosols have substantial impacts on the Earth's climate through their direct, semi-direct and indirect effects. This is the reason why it is essential to include the description of aerosol processes (sources, evolution during transport, deposition, chemical, physical and optical properties) in regional and global climate models. According to IPCC (2007), the aerosol radiative forcing estimated in 2005, relative to the preindustrial year 1750, is negative at the global scale $\left(-0.5 \mathrm{~W} \mathrm{~m}^{-2}\right.$ for the direct effect and $-0.7 \mathrm{~W} \mathrm{~m}^{-2}$ for the cloud albedo effect), with a large uncertainty notably due to their huge spatial and temporal variability. Not only can different natural processes emit aerosols, namely desert dust lifting, sea spray, volcanic explosions or biogenic organic emissions, but anthropogenic activities can also be a significant contributor, notably because of biomass burning, fossil fuels combustion and industrial production. Aerosols have generally short atmospheric life times (from a few days to several weeks), are associated with local sources, and possibly undergo rapid chemical evolution, thereby affecting transport and removal processes (e.g. Sullivan et al., 2007). Their physicochemical and optical properties are 
consequently highly variable in space and time. These properties determine their interactions with shortwave (SW) and longwave (LW) radiation and clouds, with ensuing impacts on climate. As representative of this complexity, the Mediterranean basin has been identified by Lelieveld et al. (2002) as a crossroads of air masses carrying numerous and various aerosols. In this region, aerosols of different sources accumulate: industrial and urban aerosols from Europe and North African towns, biomass burning aerosols from Eastern Europe, dust aerosols from Africa, and marine particles from the sea. Basart et al. (2009) outline the resulting large variety in aerosol properties over the basin. Given this high aerosol content in this region, their effects can be important to the climate and ecosystems of the Mediterranean. Regional climate response to aerosol is all the more complex as local winds, complex coastlines and orography have strong interactions in the atmospheric flow. In this context, high resolution modeling in this region is essential (Gao et al., 2006; Giorgi and Lionello, 2008; Colin et al., 2010; Herrmann et al., 2011), and the use of a regional climate model (RCM) to investigate these effects is particularly relevant.

Desert dust is on average the principal aerosol component over the basin and strongly influences the Mediterranean climate (Barnaba and Gobbi, 2004). Desert dust aerosols come from suspension, saltation and creeping processes associated with wind erosion (Shao, 2008; Kok et al., 2012). Dust emission is not a homogeneously continuous phenomenon, and mostly occurs in episodic events of intense near-surface wind conditions, able to lead to dust outbreaks over the Mediterranean Sea (Moulin et al., 1997). Dust aerosols can be lifted up to high altitudes, namely between 1.8 and $9 \mathrm{~km}$ (Mona et al., 2006; Kalivitis et al., 2007), especially for the finer particles, and then be transported over thousands of kilometres. They potentially play an important role in the climate system because of their optical properties (absorption and scattering of infrared and solar radiation, as well as emission of infrared radiation, Slingo et al., 2006), which modify the Earth's radiative budget through complex mechanisms (Sokolik et al., 2001). They also influence biogeochemistry, as dust deposition to the ocean is an important source of iron in highnutrient-low-chlorophyll (HNLC) regions (Mahowald et al., 2009; de Madron et al., 2011), which is crucial for phytoplankton growth. Many global climate models simulate dust emission and transport in a coherent manner (Woodage et al., 2010), but the total impact of dust aerosols on Earth's radiative budget still constitutes an important uncertainty (IPCC, 2007; Kok, 2011a). There are large differences in global climate models in the simulation of the dust cycle and the resulting impact on climate (Huneeus et al., 2011). A large inter-model variability is also found at the regional scales (Uno et al., 2006), notably due to differences in dust emission parameterizations (Todd et al., 2008). Numerous parameters such as soil properties, surface wind and roughness variability are responsible for emission uncertainties, affecting saltation and the total emission mass flux. Another component of these uncertainties comes from the representation of the emission dust size distribution. Different approaches have been proposed to parameterize this distribution. The first approach consists in directly assigning a representative size distribution to the integrated vertical mass flux from measurements. In global modeling a background size distribution is often considered (e.g. Zender et al., 2003), which could be potentially unrealistic close to emitting regions. When local emission distribution data are available, this approach has proved to be regionally more realistic (Crumeyrolle et al., 2011) but is a priori tied to a specific domain of study. A second approach, notably used by Alfaro and Gomes (2001) and Shao (2001), consists of using a physically explicit scheme to link the emission size distribution to both the wind speed at emission and soil properties such as the size distribution, aggregate binding energy, and soil plastic pressure. However, many of these parameters are difficult to measure and even more difficult to scale up over extended geographic domains. The most recent approach for representing the dust size distribution at emission is to use the analogy of the fragmentation of brittle materials such as glass with the emission of dust aerosols through the cracking of soil aggregates (Kok, 2011a). In contrast to the schemes of Alfaro and Gomes (2001) and Shao (2001), this approach results in a size distribution that is independent of wind speed (Kok, 2011b). This is consistent with measurements of the dust size distribution at emission (Gillette, 1974; Shao et al., 2011), and had previously been hypothesized by Reid et al. (2008) based on the observation that the in situ dust size distribution is relatively independent to changes in wind speed. Moreover, Kok (2011a) has suggested that the relatively small amount of scatter between measurements suggests that the dust size distribution at emission is also relatively independent of the regional soil properties, and used this observation to propose a universal size distribution.

The present study explores the sensitivity of a regional climate model (RegCM-4) to these different approaches in representing dust emission distribution, and the impact it can have on the dust budget (emission, concentration, dry and wet deposition), associated aerosol optical depth (AOD) and aerosol direct radiative forcing, both in SW and LW radiation. In order to find the most realistic distribution, two simulations have been performed for the year 2008. The objective is also to characterize the aerosol optical depth, emission and deposition in the Mediterranean over a ten-year period in order to estimate their potential impact on climate through direct SW and LW radiative forcing. It should be noted that only the direct effect of aerosols is considered in the present work. After a description of methodology in Sect. 2, we focus on both dust particle size distributions in Sect. 3. Results of a comparison on dust outbreaks over the Mediterranean are then evaluated against satellite and surface remote-sensing observations in Sect. 4. Section 5 presents the results at the seasonal scale, and the aerosol characteristics over a longer 
period before our summary and concluding remarks detailed in Sect. 6.

\section{Methodology}

\subsection{The RegCM-4 model}

The Regional Climate Model system, namely RegCM, has been developed since 1989 at the National Center for Atmospheric Research (NCAR, Dickinson et al., 1989) and then at the International Centre for Theoretical Physics (ICTP, Trieste - Italy, Giorgi and Mearns, 1999). The current version used in this study is RegCM-4 (Giorgi et al., 2012). The main characteristic of this model is to be user-friendly and highly portable to a variety of computer platforms. It can also interface with many reanalyses, such as the European Centre for Medium-range Weather Forecasts (ECMWF, Sylla et al., 2009) or the National Center for Environmental Prediction (NCEP), and the GCM (Global Climate Model) boundary conditions to provide a full suite of simulation options. Its horizontal resolution can vary from 10 to $100 \mathrm{~km}$, for simulation periods can vary from days to decades. It is a hydrostatic, sigma vertical coordinate model (18 levels), whose dynamical core is historically based on the hydrostatic version of the fifth generation of the mesoscale model MM5 (Grell et al., 1994). The formation of precipitation is divided between resolvable (or large-scale) precipitation using the subgrid explicit moisture SUBEX scheme (Sundqvist et al., 1989), and convective precipitation using in the present work the MITEmanuel scheme (Emanuel, 1991). The biosphere is taken into account thanks to BATS (Biosphere-Atmosphere Transfer Scheme, Dickinson et al., 1993), which gives the transfer of energy, mass and momentum between the atmosphere and biosphere. There is no two-way interaction between the ocean and the atmosphere. Fluxes from open bodies are only computed from prescribed sea surface temperatures (SSTs), so that the atmosphere cannot affect the ocean.

In RegCM-4, the basic aerosol scheme accounts for sulfate, organic carbon, black carbon, dust and sea salt aerosols, and is described by Qian et al. (2001) and Solmon et al. (2006). Assuming an external mixture, it includes advection by atmospheric winds, diffusion by turbulence, vertical transport by deep convection, surface emissions, dry and wet removal processes, and gas and aqueous phase chemical conversion mechanisms.

The emission terms of the anthropogenic aerosols come from different inventories based on reference years. Dust and sea salt emissions are based on Zakey et al. (2006, 2008) with modifications described in Giorgi et al. (2012). Different studies have shown the ability of RegCM-4 to reproduce the basic regional patterns and seasonality of the different aerosols over Europe and Africa (e.g. Solmon et al., 2006). The SW radiative effect is calculated using optical properties (asymmetry factor, Single Scattering Albedo (SSA) and mass extinction coefficient), which are computed for each aerosol type and each wavelength of the RegCM-4 radiation scheme (18 wavelength bands, Kiehl et al., 1996) using a Mie scattering code. The LW emissivity and absorptivity are calculated using prognostic dust bin concentrations, LW refractive indices and absorption cross sections consistent with Wang et al. (2006). Even though the present study focuses on dust aerosols, the presence of all aerosol types in RegCM-4 enables us to compare total AOD with satellite measurements. RegCM-4 based aerosol regional climate impacts have been carried out over different regions, such as East Asia (Zhang et al., 2009; Yan et al., 2011), West Africa (Sylla et al., 2010; Solmon et al., 2008; Konare et al., 2008; Malavelle et al., 2011; Solmon et al., 2012) and South Africa (Tummon et al., 2010). As far as the Mediterranean is concerned, studies have been led about dust outbreaks (Santese et al., 2010), but it is the first time to our knowledge that a longer simulation with a coupled-chemistry regional climate model including dust aerosols has been proposed in this region.

The simulations of this study use boundary conditions from ERA-INTERIM (Dee et al., 2011). These data, coming from the ECMWF, are a reanalysis of the period 1979present in preparation for the next-generation extended reanalysis to replace ERA-40. Aerosols are not included in the lateral boundary conditions, and we have defined the domain in order to account for the main aerosol sources over the Mediterranean basin, notably the Saharan dust (Israelevich et al., 2012).

The latter extends from 25 to $55^{\circ} \mathrm{N}$ and from -10 to $45^{\circ} \mathrm{E}$ and represents a region of 4750 by $3600 \mathrm{~km}$, with a resolution of $50 \mathrm{~km}(120 \times 97$ points in the grid model $)$. At each extremity, 12 grid points constitute the buffer zone, where a relaxation method allows a smooth transition in order to avoid an abrupt change between the RCM simulation and the lateral boundary conditions, and reduces noise generation. Outputs for all the simulations performed in this study are provided every $6 \mathrm{~h}$.

\subsection{Observation data}

The simulated aerosol optical depth (AOD) will be compared with satellite data from the MODerate resolution Imaging Spectroradiometer (MODIS), the Cloud-Aerosol LIdar with Orthogonal Polarization (CALIOP) instrument and in-situ observations from the AErosol RObotic NETwork (AERONET). The year 2008 has been chosen for the RegCM-4 simulation and the comparison because of the availability of these three kinds of data.

MODIS is a passive radiometer, based on NASA's Aqua satellite, designed to retrieve aerosol optical and microphysical properties over land and ocean (Tanré et al., 1997; Levy et al., 2007). Over bright surfaces such as the Saharan desert, a specific algorithm called "Deep Blue" is used (Hsu et al., 2004). It is based on the blue wavelengths and libraries of surface reflectance, and enables the retrieval of AOD on 
regions where the land algorithm, which relied on finding dark targets, is inadequate. For this study, we have used the Level-3 aerosol products (collection 5.1, standard and Deep Blue algorithms) at the $1 \times 1^{\circ}$ resolution.

CALIOP is an instrument based on the Cloud-Aerosol Lidar and Infrared Pathfinder Satellite Observations (CALIPSO) satellite. Launched in April 2006, its purpose is to study the impact of clouds and aerosols on the Earth's radiation budget and climate (Vaughan et al., 2004; Winker et al., 2009). It has the advantage that it retrieves the vertical profiles of aerosol properties compared to standard radiometers that provide aerosol properties only for the atmospheric column. In this study the vertical distribution of aerosol types is of particular interest, since it allows us to follow the transport of dust aerosols (especially their altitude) over the Mediterranean basin. These comparisons with CALIOP are just used to assess the vertical distribution of aerosols, and we used it in synergy with the total AOD estimated from passive surface and satellite techniques (Bréon et al., 2011).

AERONET is a ground-based internationally federated, globally distributed network of automatic sun/sky radiometers (Holben et al., 1998, 2001). Sunphotometer observations are used to retrieve AOD at different wavelengths and also the microphysical (volume size distribution) together with optical (refractive index, SSA and asymmetry parameter) properties for the whole atmospheric column following the algorithm detailed in Dubovik and King (2000). Associated uncertainties of the different aerosol parameters are provided in this article. In the present work, we have mainly used the AOD data (daily average quality-assured data - Level 2.0 - downloaded from the AERONET website: http://aeronet.gsfc.nasa.gov).

\subsection{Taylor diagrams}

To evaluate the model more precisely, we will use Taylor diagrams. Presented in Taylor (2001), they are twodimensional graphs which indicate how closely a pattern matches observation. Every Taylor diagram represents three statistics, namely the correlation coefficient (indicated by the azimuthal angle), the standard deviation normalized by the observed standard deviation (the radial distance from the origin) and the root-mean-square (RMS) difference (the distance to the point on the $\mathrm{x}$-axis identified as "observed"). The distance between the points representing the simulation and the observation can be seen as a measure of the error: it is the bias-corrected RMS difference. Thus, it enables a quick comparison of several simulations, for instance in terms of seasonal means or interannual variability.

\section{Simulation design}

This study investigates the particle size distribution for the emitted dust vertical flux. In the regional climate model
RegCM-4, the physical dust emission scheme consists of two processes: saltation and sandblasting, based on the studies of Marticorena and Bergametti (1995) and Alfaro and Gomes (2001). Particles of $\sim 100 \mu \mathrm{m}$ are most readily lifted by wind, because the lifting of smaller and larger particles is impeded by increases in the strength of the cohesive and gravitational forces, respectively, relative to aerodynamic forces (Iversen and White, 1982; Kok et al., 2012). These particles are submitted to ballistic trajectories (saltation), and are transported by wind. When these saltating particles fall down, their impacts eject dust particles $(\sim 0.1-50 \mu \mathrm{m})$ from dust aggregates in the soil (sandblasting). This is the main dust emission process contributing to the dust vertical flux (Shao et al., 1993).

In the current parameterization of RegCM-4, a minimum value of the wind friction velocity is necessary in order for saltation to occur (Marticorena et al., 1997); otherwise the particles cannot be lifted. This erosion threshold depends on the dry soil distribution, on the soil moisture and on the roughness due to the presence of nonerodible elements.

The soil moisture effect on the particle cohesive forces and the erosion threshold is also taken into account (Fécan et al., 1999). Many theoretical and experimental studies (Gillette, 1979; Shao et al., 1993) have shown that the horizontal flux $(G)$, namely the saltation flux, is proportional to the third power of the wind friction velocity. The dust vertical flux is then inferred from the saltation flux, since the dust aerosol production corresponds to the rupturing of the interparticle bonds linking dust particles to each other or to the surface (Alfaro et al., 1997). In this approach, the emitted mass and the distribution depend on the individual kinetic energy of the aggregates striking the surface. Alfaro and Gomes (2001) proposed a distribution based on three lognormally distributed modes, related to three binding energies determined from wind tunnel experiments. These energies correspond to different thresholds of disruption of the aggregates. When the kinetic energy of an individual saltating aggregate of given size reaches the threshold of one binding energy, particles from this mode are released.

Even if the dust emission process as described by $\mathrm{Al}-$ faro and Gomes (2001) is qualitatively understood, quantifying emissions is still difficult. Indeed, cohesive forces on PM20 (soil particles smaller than $20 \mu \mathrm{m}$ ) are poorly understood (Shao, 2001), which causes large uncertainties in these theoretical predictions of the size distribution of emitted dust aerosols. It is suggested in Kok (2011a) that this representation possibly overestimates the fine dust fraction in climate models.

Recently, Kok (2011a) has pointed out that dust emission is actually analogous to another phenomenon which is better understood: the fragmentation of brittle materials. Just like an object of glass or gypsum will fragment upon receiving an impact of sufficient energy, a dry soil aggregate can also fail after the impact of a saltating particle. More precisely, three different regimes exist to classify the resulting particle size distribution: the elastic regime (low impact energy, 
no fragments produced), the damage regime (larger impact energies, several fragments of which the largest one is comparable in size to the original object) and the fragmentation regime (even larger impact energies, producing fragments of a wide range of sizes). Conveniently, the size distribution of fragments in the fragmentation regime is "scale invariant" (i.e. follows a power law) for a limited size regime. Assuming that most dust emission is due to fragmenting impacts and that the production of aerosols of size $D_{\mathrm{d}}$ is proportional to the volume fraction of soil particles with size $D_{\mathrm{s}} \leq D_{\mathrm{d}}$, Kok (2011a) derived the following equation for the volume size distribution of emitted dust aerosols:

$$
\frac{\mathrm{d} V_{\mathrm{d}}}{\mathrm{d} \ln D_{\mathrm{d}}}=\frac{D_{\mathrm{d}}}{c_{\mathrm{V}}}\left[1+\operatorname{erf}\left(\frac{\ln \left(D_{\mathrm{d}} / D_{\mathrm{s}}\right)}{\sqrt{2} \ln \sigma_{\mathrm{s}}}\right)\right] \exp \left[-\left(\frac{D_{\mathrm{d}}}{\lambda}\right)^{3}\right],
$$

where $V_{\mathrm{d}}$ is the normalized volume of dust aerosols with size $D_{\mathrm{d}}, \lambda$ is the side crack propagation length and $c_{V}$ is a normalization constant. The geometric standard deviation $\sigma_{\mathrm{s}}$ and the median diameter by volume $D_{\mathrm{s}}$ describe the lognormal distribution of fully disaggregated soil particles. Kok (2011a) used least-squares fitting on measured particle size distribution of arid soils to determine $D_{\mathrm{s}}=3.4 \pm 1.9 \mu \mathrm{m}$ and $\sigma_{\mathrm{s}}=3.0 \pm 0.4 \mu \mathrm{m}$.

This new dust size distribution has been compared to field measurements of the size-resolved vertical dust flux in Kok (2011a), where excellent agreement was found between theory and measurements over a sample of data. Moreover, these measurements suggest that previously used empirical model relations could overestimate the mass fraction of emitted clay aerosols $\left(D_{\mathrm{d}}<2 \mu \mathrm{m}\right)$ and underestimate the fraction of emitted large silt aerosols $\left(D_{\mathrm{d}}>5 \mu \mathrm{m}\right)$. Consequently, these estimate errors could cause model errors, especially in the spatial distribution of dust, and in the balance between dust radiative cooling and heating (Kok, 2011a). We will study more precisely the impact of this change of distribution in RegCM-4 over the Mediterranean region in Sects. 4 and 5.

In order to implement this new distribution for the dust vertical flux in RegCM-4, we will keep the same calculation for the horizontal saltation flux $G$ previously described in this section. The vertical flux $F$ will then be deduced with an empirical relationship given by Marticorena and Bergametti (1995), using the soil clay content \% clay:

$\alpha=\frac{F}{G}=c_{\text {alpha }} \times 10^{0.134 . \% \text { clay }-6}$,

where $c_{\text {alpha }}$ is a normalization constant adapted to have a value of $\alpha$ relevant compared to the one used in other models (see Todd et al., 2008), using $c_{\text {alpha }}=0.035$. The dust size distribution of Kok (2011a) can then be applied to this emitted vertical flux. It should be outlined that this change of parameterization also modifies the total integrated emitted dust flux. This aspect will be taken into account in the following discussions. Another important point is that dust bin optical properties are kept constant between the two parameterizations.

\section{Results: comparison of both distributions at the episodic scale}

As mentioned in Sect. 1, the aim is to evaluate the impact of the new dust size distribution on the dust aerosol load, deposition and direct radiative forcing, both at the episodic and seasonal scale. We perform simulations with both the Alfaro and Gomes (2001) and the new Kok (2011a) size distribution, which we refer to as the REF and the NEW simulation, respectively. From the point of view of climate, the long temporal scales are the most critical, but given their intermittent nature, evaluating dust events is a first necessary step to assess the realism of emission and transport processes. In this section, we consider the event scale first with two dust outbreaks over the Mediterranean in 2008 and then with daily temporal series in three AERONET stations. Different regions of the Mediterranean basin have been chosen for these outbreaks in order to take into account the possible different responses according to wind conditions and soil properties.

Spring and early summer are the favourable period for the "sharav cyclones", which tend to move along the Northern African coast and cross the Mediterranean towards the north between Tunisia and Egypt, bringing dust to these regions (Moulin et al., 1998). On the contrary, in summer and autumn, dust transport is concentrated over the central and western basins because of the Saharan depression combined with the semi-permanent ridge over Libya (Gkikas et al., 2012; Israelevich et al., 2012). The following two examples illustrate both these situations. For each case, the different parameters characterizing aerosols (such as AOD and deposition) are averaged over the corresponding period and domain, both for MODIS and RegCM-4 data.

\subsection{Case 1: 31 October-2 November 2008}

The first case occurred in early November 2008, when a dust plume blew from the Sahara across the Mediterranean Sea toward Europe. Figure 1d shows this phenomenon captured by MODIS. The plume might come from sand seas in Algeria, namely between Grand Erg Oriental near the Algeria-Libya border, and Grand Erg Occidental. It is crossing the sea, mixing with clouds over Greece. MODIS AOD (Fig. 1a) shows the trace between the Algeria-Libya border and Greece, with values up to 0.8 at $550 \mathrm{~nm}$. With regards to RegCM-4 experiments, REF (Fig. 1b) clearly overestimates AOD over this region. NEW (Fig. 1c) is in better agreement with MODIS, given the narrow band of AOD between 0.6 and 0.7 between Libya and Greece. However, some discrepancies appear in the African continent. The Taylor diagram (Fig. 1e) shows a reduced error for NEW experiment, notably for the simulated standard deviation ( 0.12 over the affected zone during the episode) much closer to the observed standard deviation (0.13 for MODIS) than REF experiment (0.42). The RMS difference is consequently reduced in NEW (1.32) compared to REF (3.09). 
Table 1. Average dust emission, integrated concentration, optical depth $(550 \mathrm{~nm})$ and deposition during the outbreak (31 October-2 November 2008$)$ over the affected zone $\left(25-43^{\circ} \mathrm{N}, 5-30^{\circ} \mathrm{E}\right)$ for each dust bin. 1: 0.01-1.0 $\mu \mathrm{m}, 2: 1.0-2.5 \mu \mathrm{m}, 3: 2.5-5.0 \mu \mathrm{m}, 4: 5.0-20.0 \mu \mathrm{m}$. The largest value for each bin is indicated in boldface. The normalized value (for a total emission of $1000 \mathrm{mg} \mathrm{m}^{-2} \mathrm{day}^{-1}$ ) of each term is indicated between brackets, and in a specific line for the emission of each bin.

\begin{tabular}{|c|c|c|c|c|c|c|c|c|c|c|}
\hline \multirow{2}{*}{$\begin{array}{l}\text { Parameter } \\
\text { Dust bin }\end{array}$} & \multicolumn{5}{|c|}{$\mathrm{REF}$} & \multicolumn{5}{|c|}{ NEW } \\
\hline & 1 & 2 & 3 & 4 & $\begin{array}{l}\text { Total } \\
\text { (norm) }\end{array}$ & 1 & 2 & 3 & 4 & $\begin{array}{l}\text { Total } \\
\text { (norm) }\end{array}$ \\
\hline $\begin{array}{l}\text { Emission } \\
\text { (normalized) } \\
\left(\mathrm{mg} \mathrm{m}^{-2} \text { day }^{-1}\right)\end{array}$ & $\begin{array}{l}65.9 \\
(96.6)\end{array}$ & $\begin{array}{l}73.5 \\
(107.8)\end{array}$ & $\begin{array}{l}20.5 \\
(30.0)\end{array}$ & $\begin{array}{l}521.9 \\
\mathbf{( 7 6 5 . 6 )}\end{array}$ & $\begin{array}{l}681.7 \\
(1000)\end{array}$ & $\begin{array}{l}14.8 \\
(15.5)\end{array}$ & $\begin{array}{l}61.2 \\
(63.9)\end{array}$ & $\begin{array}{l}214.7 \\
(224.2)\end{array}$ & $\begin{array}{l}\mathbf{6 6 6 . 9} \\
(696.4)\end{array}$ & $\begin{array}{l}957.6 \\
(1000)\end{array}$ \\
\hline $\begin{array}{l}\text { Column burden } \\
\left(\mathrm{mg} \cdot \mathrm{m}^{-2}\right)\end{array}$ & 110.5 & 51.3 & 11.4 & 77.6 & $\begin{array}{l}250.8 \\
(367.8)\end{array}$ & 25.5 & 45.5 & 127.5 & 102.9 & $\begin{array}{l}301.4 \\
(314.7)\end{array}$ \\
\hline $\begin{array}{l}\text { Optical depth } \\
(550 \mathrm{~nm})\end{array}$ & 0.27 & 0.04 & 0.01 & 0.01 & $\begin{array}{l}0.33 \\
(0.49)\end{array}$ & 0.06 & 0.04 & 0.05 & 0.02 & $\begin{array}{l}0.17 \\
(0.18)\end{array}$ \\
\hline $\begin{array}{l}\text { Dry deposition } \\
\left(\mathrm{mg} \mathrm{m}^{-2} \text { day }^{-1}\right)\end{array}$ & 14.8 & 30.4 & 9.0 & 296.2 & $\begin{array}{l}350.4 \\
(514.0)\end{array}$ & 3.0 & 24.1 & 92.2 & 386.6 & $\begin{array}{l}505.9 \\
(528.3)\end{array}$ \\
\hline $\begin{array}{l}\text { Wet deposition } \\
\left(\mathrm{mg} \mathrm{m}^{-2} \text { day }^{-1}\right)\end{array}$ & 1.3 & 0.7 & 0.2 & 0.9 & $\begin{array}{l}3.1 \\
(4.4)\end{array}$ & 0.2 & 0.4 & 1.2 & 1.0 & $\begin{array}{l}2.8 \\
(3.0)\end{array}$ \\
\hline
\end{tabular}

(a) - MODIS

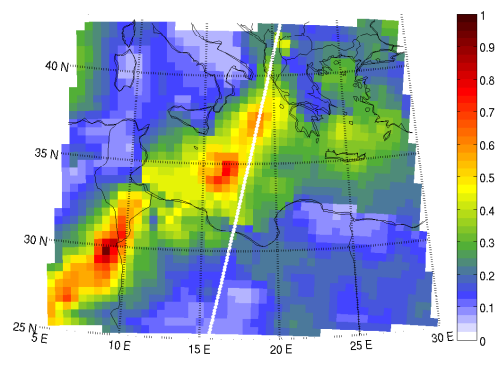

(d) - Visible (b) - REF

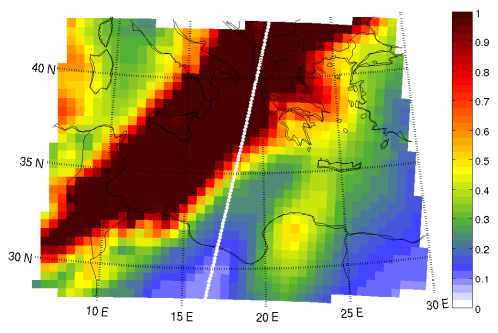

(c) - NEW

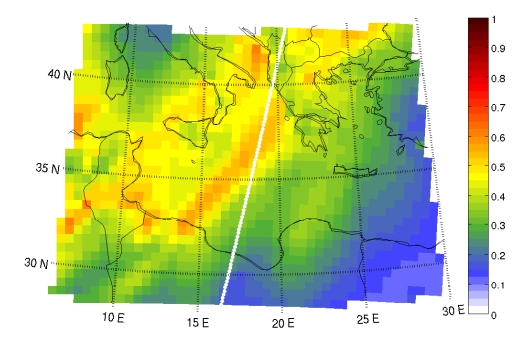

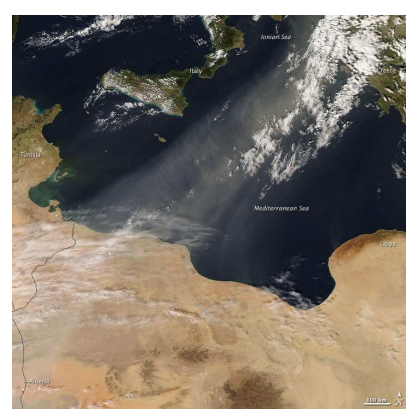

(e) - Taylor diagram

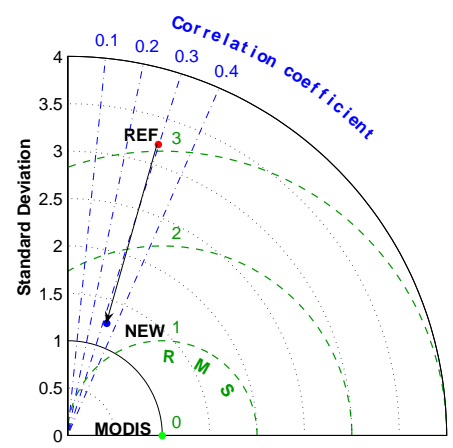

Fig. 1. Dust event between 31 October and 2 November 2008 - Comparison of aerosol optical depth (AOD) at 550 nm between MODIS data (a), REF (b) and NEW (c). White line: the trace of CALIOP on 1 November 2008, see Fig. 2 - at the bottom: satellite image from MODIS on 1 November (d) and corresponding Taylor diagram (e).

Table 1 presents different dust parameters (emission, column burden, AOD, dry and wet deposition) for each dust bin, on average over the affected region $\left(25-43^{\circ} \mathrm{N}, 5-30^{\circ} \mathrm{E}\right)$. The normalized values for a total emission of $1000 \mathrm{mg} \mathrm{m}^{-2}$ day $^{-1}$ are also indicated in order to take into account the change in the total emitted mass. It should be noted for this budget that emitted dust aerosols outside the affected region could also have been modified. In terms of mass, emitted fine aerosols (smaller than $2.5 \mu \mathrm{m}$ ) are prevailing with the Alfaro scheme (REF), contrary to the Kok distribution (NEW) which enhances the coarse bin. This shift to larger dust sizes in the change from Alfaro to the Kok scheme is also reflected in the 
simulated dust concentration and deposition. In total mass, these two terms have increased, but compared to the total dust emitted flux, the proportion of atmospheric dust content has decreased, and dust deposition within the affected domain slightly increased. Fine aerosols, prevailing in mass in the REF simulation, have longer atmospheric lifetimes (e.g. Tegen and Lacis, 1996), and are thus deposited further from source regions than coarse dust aerosols. With regards to AOD, only the first bin shows a big difference between the REF and NEW simulations, because fine aerosols have the strongest impact on SW radiation extinction (e.g. Tegen and Lacis, 1996). Despite the fact that the total emitted flux has increased with the new distribution, dust AOD has decreased substantially in the NEW simulation. On average over the affected region, total AOD from NEW is 0.30 against 0.46 for REF, while MODIS AOD is 0.24. This decrease in AOD is even more sensitive with the normalized values. Indeed, the average extinction given by the ratio between the AOD and the column burden is higher in $\operatorname{REF}\left(1.3 \mathrm{~m}^{2} \mathrm{~g}^{-1}\right)$ than in NEW $\left(0.56 \mathrm{~m}^{2} \mathrm{~g}^{-1}\right)$.

Figure 2 presents the vertical profile of aerosols measured by CALIOP on 1 November 2008. Both REF and NEW simulate the presence of dust aerosols at a similar altitude as CALIOP, which is to say between 500 and $4000 \mathrm{~m}$. Further from the sources (around $40^{\circ} \mathrm{N}$ in latitude), REF probably overestimates the presence of dust aerosols in altitude compared to NEW and CALIOP. However, the presence of high clouds beyond $38^{\circ} \mathrm{N}$ might disturb the identification of dust aerosols in lower troposphere by CALIOP.

These simulated differences in the size distribution, loading and altitude of the dust also impact the direct radiative forcing (RF) at the regional scale. The RF is the difference between the net fluxes in the presence and absence of atmospheric aerosols (for the exact same atmosphere). The surface (resp. TOA) net flux $\left(F_{\text {net }}\right)$ is the difference between the downward and upward irradiances at the Earth's surface (resp. TOA). It can be computed for LW or SW radiation. Figure 3 presents aerosol radiative forcing (shortwave and longwave) at the surface and at the top of the atmosphere (TOA). In the REF simulation, the presence of many fine aerosols, which produce a strong cooling effect through efficient scattering of SW radiation (Liao and Seinfeld, 1998; Miller et al., 2006), increases the negative forcing both at the TOA and at the surface, resulting in an RF up to $\sim 20$ and $30 \mathrm{~W} \mathrm{~m}^{-2}$ at TOA and the surface, respectively. Since the size distribution of the NEW simulation contains a much smaller mass fraction of fine dust aerosols (Table 1 ), the RF is decreased by $\sim 50 \%$ to maximum values of $\sim 5$ and $15 \mathrm{~W} \mathrm{~m}^{-2}$ at TOA and the surface, respectively, despite higher total emission and burden (Table 1). Moreover, over the North African continent, the sign of RF has changed at the TOA. This occurs because coarse dust aerosols, which are more numerous in NEW compared to fine aerosols (contrary to REF), are more absorbing in the visible spectral region. Indeed, the addition of coarse dust particles decreases

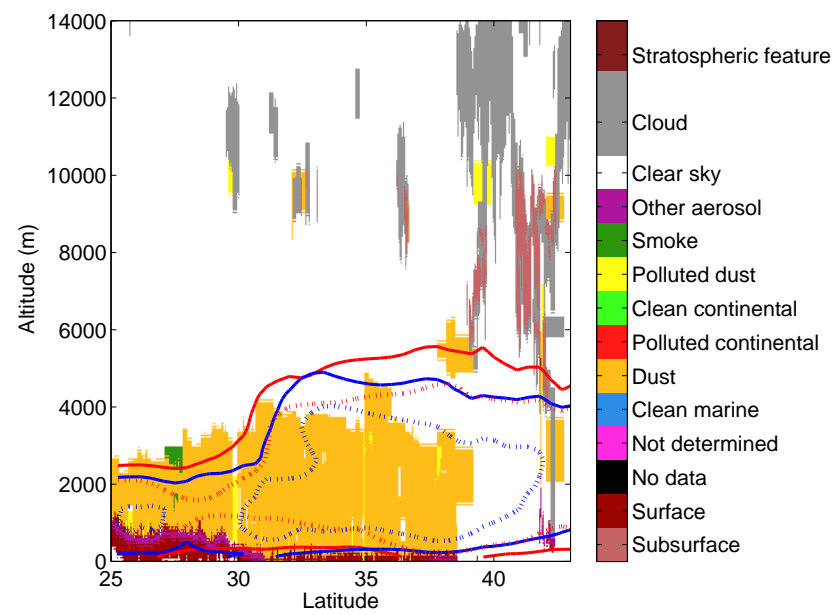

Fig. 2. Vertical profile of aerosols measured by CALIOP on 1 November 2008. The corresponding trace is plotted in Fig. 1a. The AOD of dust aerosols simulated in RegCM-4 by REF is indicated with the red line, by NEW with the blue line (solid line: dust $\mathrm{AOD}=0.01$, dashed line: dust $\mathrm{AOD}=0.03$ ).

SW SSA (McConnell et al., 2008), and thus the RF is slightly positive over this dust-emitting region. Furthermore, more coarse dust particles lead to an additional positive TOA LW forcing.

\subsection{Case 2: 23-25 March 2008}

The second case refers to a dust episode occurring in late March 2008. Figure 4 shows Saharan dust blowing northward over the Mediterranean Sea towards Turkey, then turning east and blowing over part of the Black Sea (Fig. 4d). MODIS AOD at $550 \mathrm{~nm}$ (Fig. 4a) has two maxima: one over the sea near Cyprus (1.7) and the other one in the eastern Black Sea (1.4). The latter is better seen by RegCM4 (Fig. 4b) and (Fig. 4c), especially by NEW (1.2 against 1.0 for REF). Both experiments simulate the first maximum in a different place, namely in northwestern Egypt. Compared with Deep Blue data, the inland maximum around $20^{\circ} \mathrm{E}(0.7)$ is excessively simulated by NEW (1.0) and REF (1.3), in addition to a geographic error for the latter. The correlation coefficient (Fig. 4e) is higher for the NEW experiment (0.56) than for REF (0.48), and an improvement is also noticed for the standard deviation $(0.25$ for NEW, 0.24 for MODIS and 0.27 for REF) and the RMS difference ( 0.97 for NEW instead of 1.09 for REF).

Table 2 presents the same parameters for this second case as Table 1. The same phenomenon can be noticed: the fine mode is prevailing in REF, while more coarse aerosols are emitted in NEW. However, the response of the Alfaro scheme is not exactly the same as for the first case, probably because of different wind conditions or soil characteristics, such that the difference between the two simulations for the first bin is less important. Therefore, the difference in dust 
Table 2. Average dust emission, integrated concentration and optical depth (550 nm) and deposition during the outbreak (23-25 March 2008) over the affected zone $\left(25-48^{\circ} \mathrm{N}, 6-45^{\circ} \mathrm{E}\right)$ for each dust bin. 1: 0.01-1.0 $\mu \mathrm{m}, 2: 1.0-2.5 \mu \mathrm{m}, 3: 2.5-5.0 \mu \mathrm{m}, 4: 5.0-20.0 \mu \mathrm{m}$. The largest value for each bin is indicated in boldface. The normalized value (for a total emission of $1000 \mathrm{mg} \mathrm{m}^{-2} \mathrm{day}^{-1}$ ) of each term is indicated between brackets, and in a specific line for the emission of each bin.

\begin{tabular}{|c|c|c|c|c|c|c|c|c|c|c|}
\hline \multirow{2}{*}{$\begin{array}{l}\text { Parameter } \\
\text { Dust bin }\end{array}$} & \multicolumn{5}{|c|}{ REF } & \multicolumn{5}{|c|}{ NEW } \\
\hline & 1 & 2 & 3 & 4 & $\begin{array}{l}\text { Total } \\
\text { (norm) }\end{array}$ & 1 & 2 & 3 & 4 & $\begin{array}{l}\text { Total } \\
\text { (norm) }\end{array}$ \\
\hline $\begin{array}{l}\text { Emission } \\
\text { (normalized) } \\
\left(\mathrm{mg} \mathrm{m}^{-2} \text { day }^{-1}\right)\end{array}$ & $\begin{array}{l}40.4 \\
(67.2)\end{array}$ & $\begin{array}{l}45.0 \\
(\mathbf{7 4 . 9})\end{array}$ & $\begin{array}{l}13.7 \\
(22.7)\end{array}$ & $\begin{array}{l}502.0 \\
(\mathbf{8 3 5 . 2})\end{array}$ & $\begin{array}{l}601.1 \\
(1000)\end{array}$ & $\begin{array}{l}16.4 \\
(15.5)\end{array}$ & $\begin{array}{l}67.7 \\
(63.9)\end{array}$ & $\begin{array}{l}237.5 \\
(224.2)\end{array}$ & $\begin{array}{l}737.7 \\
(696.4)\end{array}$ & $\begin{array}{l}1059.3 \\
(1000)\end{array}$ \\
\hline $\begin{array}{l}\text { Column burden } \\
\left(\mathrm{mg} \mathrm{m}^{-2}\right)\end{array}$ & 65.6 & 33.5 & 8.4 & 83.1 & $\begin{array}{l}190.6 \\
(317.2)\end{array}$ & 25.8 & 50.2 & 145.5 & 127.1 & $\begin{array}{l}348.6 \\
(329.1)\end{array}$ \\
\hline $\begin{array}{l}\text { Optical depth } \\
(550 \mathrm{~nm})\end{array}$ & 0.17 & 0.03 & 0.00 & 0.01 & $\begin{array}{l}0.21 \\
(0.36)\end{array}$ & 0.04 & 0.03 & 0.03 & 0.01 & $\begin{array}{l}0.11 \\
(0.10)\end{array}$ \\
\hline $\begin{array}{l}\text { Dry deposition } \\
\left(\mathrm{mg} \mathrm{m}^{-2} \text { day }^{-1}\right)\end{array}$ & 8.2 & 18.2 & 6.0 & 290.0 & $\begin{array}{l}322.4 \\
(536.5)\end{array}$ & 3.5 & 27.5 & 105.1 & 428.4 & $\begin{array}{l}564.5 \\
(532.9)\end{array}$ \\
\hline $\begin{array}{l}\text { Wet deposition } \\
\left(\mathrm{mg} \mathrm{m}^{-2} \text { day }^{-1}\right)\end{array}$ & 3.4 & 1.9 & 0.5 & 3.0 & $\begin{array}{l}8.8 \\
(14.6)\end{array}$ & 1.3 & 2.6 & 7.6 & 4.2 & $\begin{array}{l}15.7 \\
(14.9)\end{array}$ \\
\hline
\end{tabular}
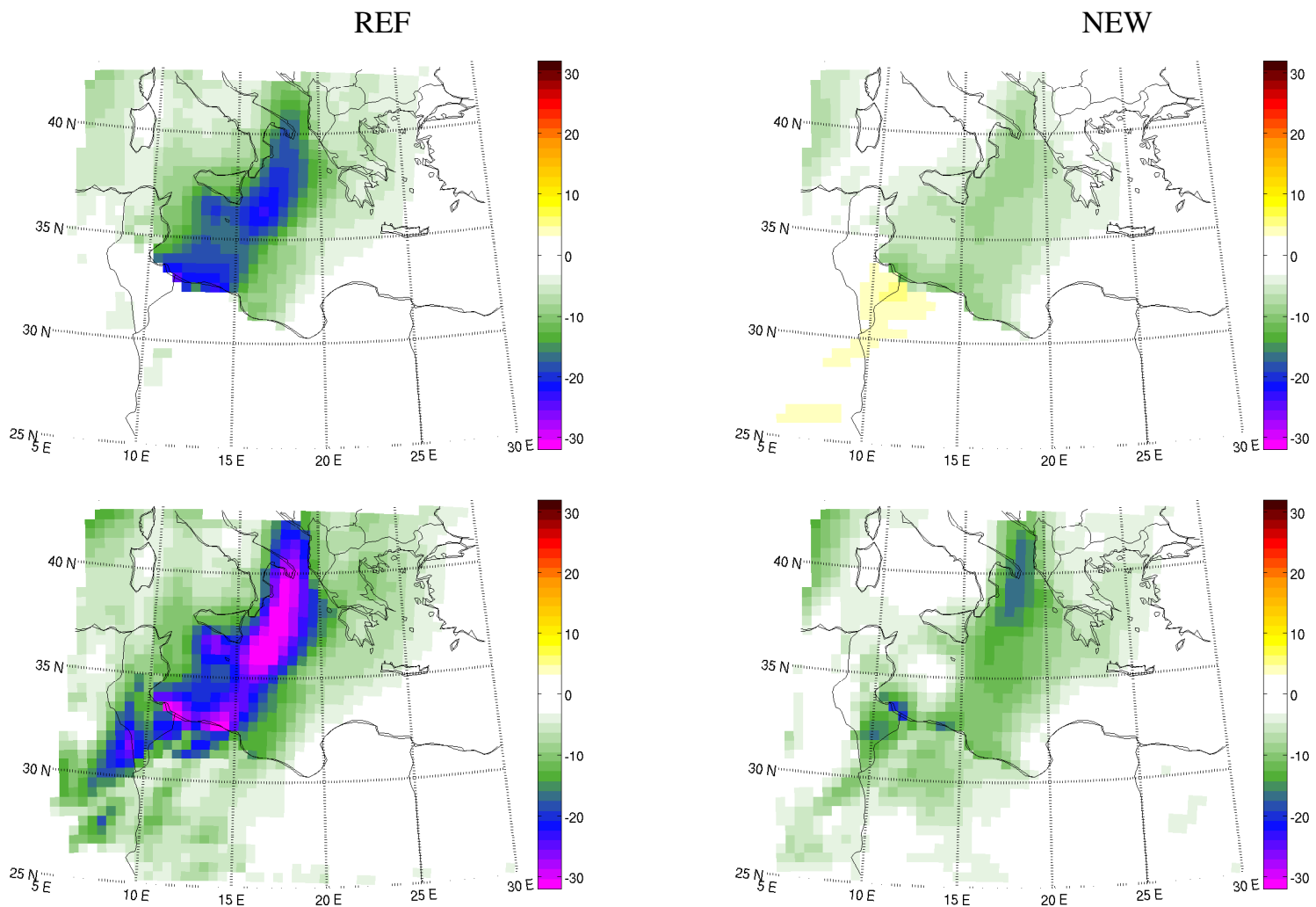

Fig. 3. Direct radiative forcing (in $\mathrm{W} \mathrm{m}^{-2}$, shortwave and longwave) simulated in REF (left panels) and NEW (right panels), at the surface (bottom panels) and at the top of the atmosphere (TOA, top panels) during the outbreak (31 October-2 November 2008).

AOD is smaller than in the first case, but AOD has still decreased in the NEW simulation. On average over the affected zone, NEW AOD $(0.30)$ is now closer to MODIS AOD (0.24) than REF AOD (0.40). Moreover, the average extinction given by the ratio between the AOD and the column burden is substantially higher in REF $\left(1.1 \mathrm{~m}^{2} \mathrm{~g}^{-1}\right)$ than in NEW $\left(0.32 \mathrm{~m}^{2} \mathrm{~g}^{-1}\right)$, as also occurred for case 1 . In terms of proportion compared with the total emitted mass, the dust column burden and dry deposition of NEW are nearly the same as in REF. With regards to radiative forcing in Fig. 5, 
(a) - MODIS

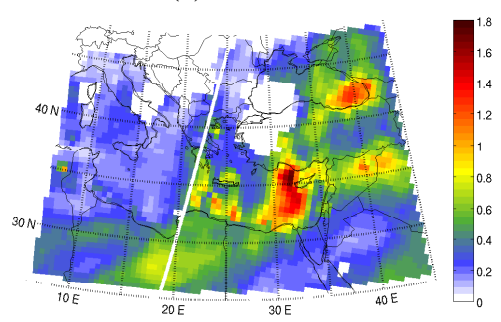

(d) - Visible

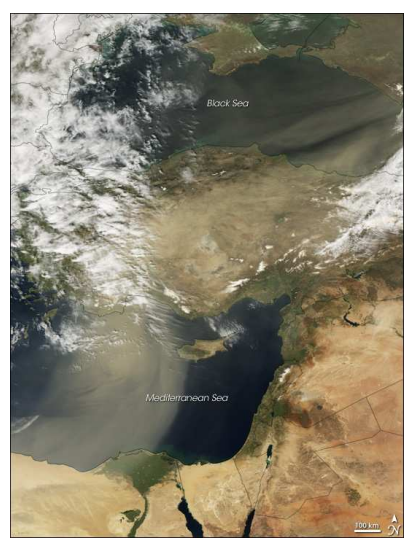

(b) - REF

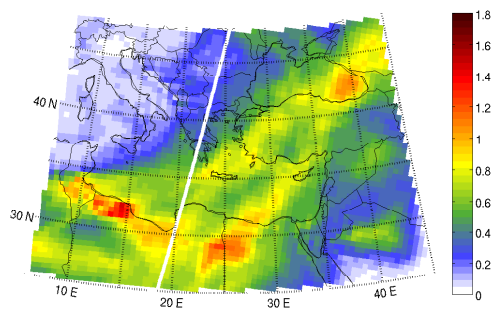

(c) - NEW

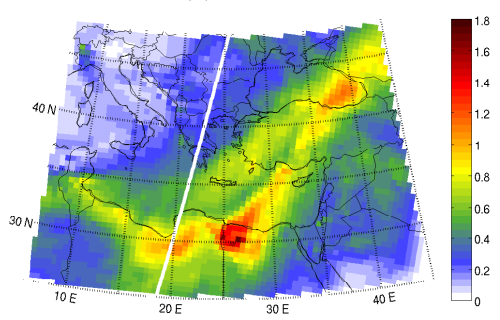

(e) - Taylor diagram

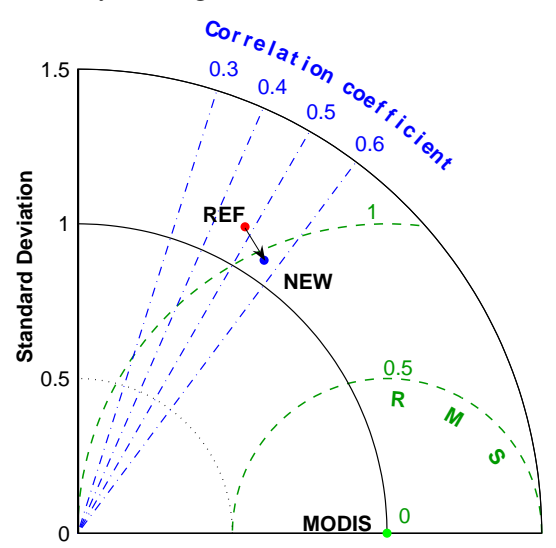

Fig. 4. Dust event between 23 and 25 March 2008 - Comparison of aerosol optical depth (AOD) at 550 nm between MODIS data (a), REF (b) and NEW (c) - white line: the trace of CALIOP on 24 March 2008, see Fig. 6. At the bottom: satellite image from MODIS on 24 March (d) and corresponding Taylor diagram (e).

values for NEW are in this case larger (in absolute terms) at the surface than for the REF simulation, notably in the eastern Black Sea where MODIS has shown a maximum AOD. At the TOA, the sign change of radiative forcing over dustemitting regions is highlighted. At the surface, the area situated east of Crete shows a positive RF. This positive sign is due to a positive LW forcing related to the presence of coarse dust aerosols, which becomes higher than the negative SW forcing (dimming).

Figure 6 presents the vertical profile of aerosols measured by CALIOP on 24 March 2008. In both simulations, dust aerosols are not emitted high enough over Africa compared to CALIOP's observations (up to $5000 \mathrm{~m}$ in CALIOP, only $3500 \mathrm{~m}$ in RegCM-4). Further from dust sources, REF shows too many dust aerosols in altitude compared to NEW and CALIOP, because of fine aerosols emitted in too large quantities in REF. This also implies a change in the dust diabatic heating profile, with possible consequences on regional climate responses.

From these two cases, we can conclude that the NEW experiment shows a significant improvement in AOD in terms of intensity and geographical positions, although some differences are still observed compared to MODIS data. This improvement is mainly due to the change in dust emission distribution rather than emitted mass.

\subsection{Dust outbreaks in AERONET data}

To confirm this evaluation, we compare the results of our simulations with AERONET data.

Three stations have been chosen in different places over the Mediterranean basin for periods when dust outbreaks took place and measurements were available. These stations are Blida (Algeria, $36.5^{\circ} \mathrm{N}, 2.9^{\circ} \mathrm{E}$ ), representing a location in the vicinity of dust sources; Barcelona (Spain, $41.4^{\circ} \mathrm{N}, 2.1^{\circ} \mathrm{E}$ ), located in the Western Mediterranean; and Crete (Greece, $35.3^{\circ} \mathrm{N}, 25.3^{\circ} \mathrm{E}$ ) in the Eastern basin. Since AERONET provides in-situ observations at specific locations, we need to interpolate the results of RegCM-4 simulations to provide AOD for the AERONET locations. The comparison is performed for AOD at $550 \mathrm{~nm}$, so that the Angstrom coefficient has been used to get AERONET values at this wavelength (Eck et al., 1999), from measurements made at $440 \mathrm{~nm}$.

In Blida (Algeria), Fig. 7a shows daily data in summer 2008. Both RegCM-4 simulations and AERONET observations show a similar evolution with time at first sight with two major peaks corresponding to dust loading maxima. However, the intensity of these maxima is generally overestimated by RegCM-4, especially by REF, which highlights the improvement in the NEW experiment. Further from dust sources, Fig. $7 \mathrm{~b}$ and $\mathrm{c}$ shows the evolution of AOD in places influenced by dust transport over the Mediterranean Sea; 

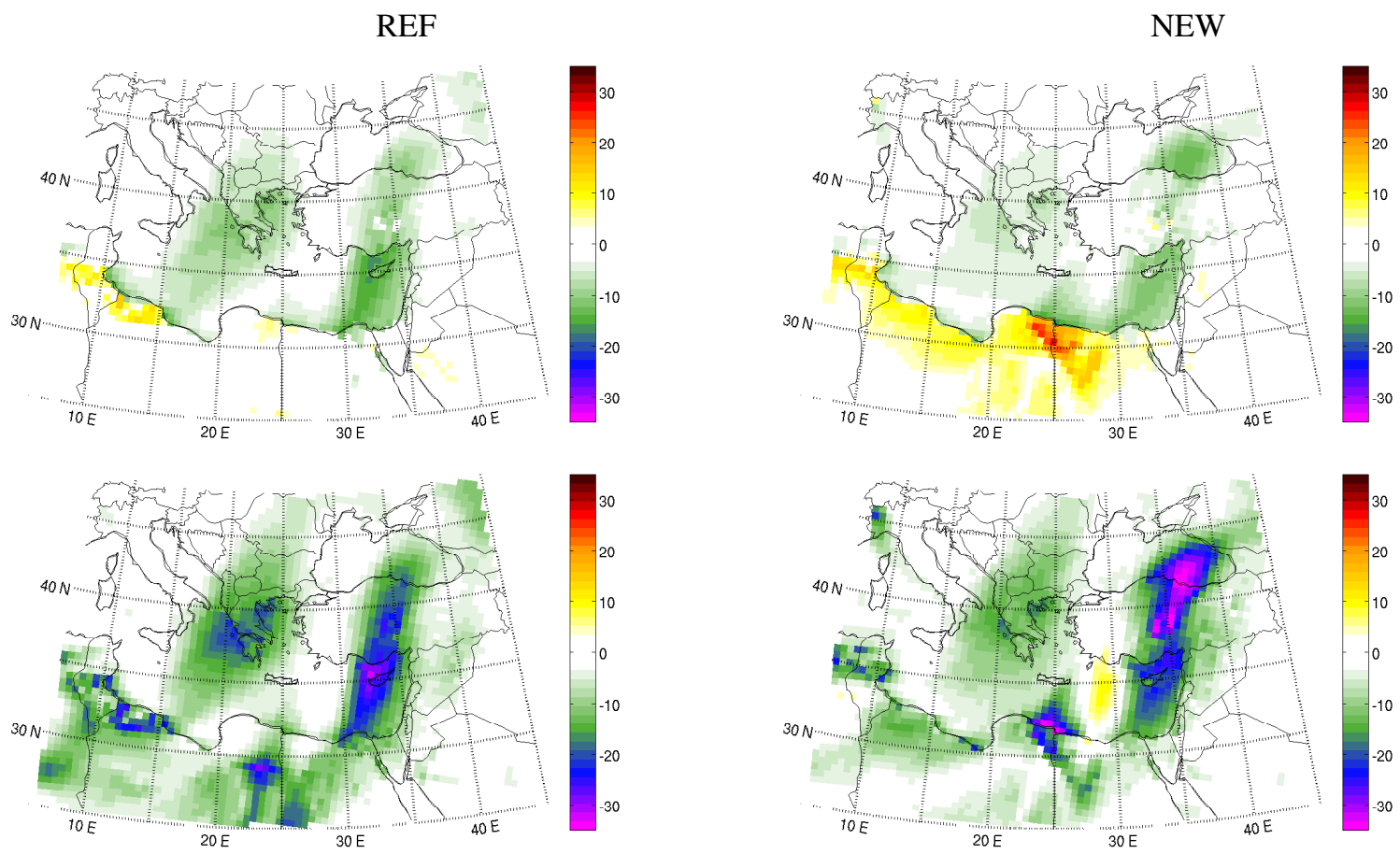

Fig. 5. Direct radiative forcing (in $\mathrm{W} \mathrm{m}^{-2}$, shortwave and longwave) simulated in REF (left panels) and NEW (right panels), at the surface (bottom panels) and at the top of the atmosphere (TOA, top panels) during the outbreak (23-25 March 2008).

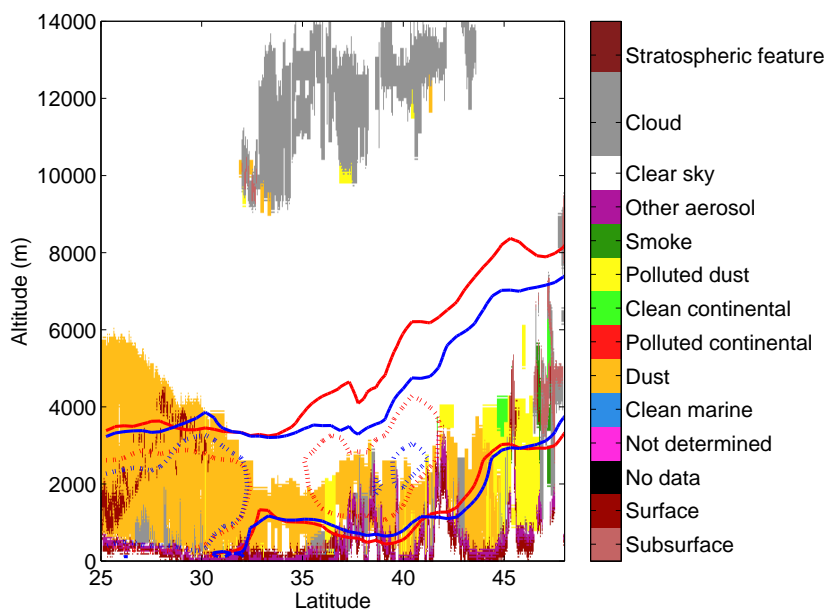

Fig. 6. Vertical profile of aerosols measured by CALIOP on 24 March 2008. The corresponding trace is plotted in Fig. 4a. The AOD of dust aerosols simulated by REF is indicated with the red line, by NEW with the blue line (solid line: dust $\mathrm{AOD}=0.01$, dashed line: dust $\mathrm{AOD}=0.03$ ).

Fig. $7 \mathrm{~b}$ refers to Barcelona in October 2008. AERONET measurements show an increase in AOD of 0.15 to 0.4 from 8 to 15 October. This increase is reproduced with the NEW simulation, whereas REF substantially overestimates it. Figure $7 \mathrm{c}$ concerns the eastern basin, namely Crete, in the favourable time period to dust outbreaks. Between
6 September and 7 December, five major peaks can be seen in the AERONET measurements. Four of them are overestimated by REF, whereas the first one is underestimated by both the REF and NEW simulations. The measured variations in AOD are qualitatively reproduced by the simulations, although NEW is in better quantitative agreement than REF.

The corresponding Taylor diagrams (Fig. 8) emphasize the improvement of the NEW simulation in the standard deviation with respect to AERONET measurements. The intensity of dust peaks is better assessed than in REF experiment and the correlation coefficient is also slightly increased.

The comparison with AERONET stations has confirmed the improvement brought by the Kok distribution at the episodic scale both close and far from dust sources. At the episodic scale, AOD is better simulated with the new distribution, due to the increase of emitted coarse dust aerosols relative to fine aerosols. Indirect validation through AOD has confirmed this choice. The question is now whether this improvement can be verified at the seasonal scale in order to apply it for a climatic objective. Therefore, in the next section we will test whether our model is able to better reproduce AOD seasonal variability in the Mediterranean area with the NEW simulation. 
(a) Blida, 03/06 - 07/08 2008

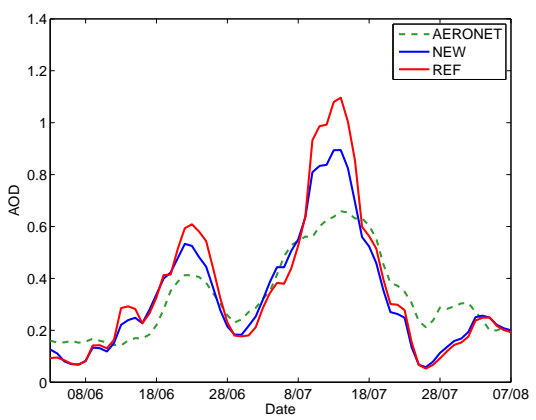

(b) Barcelona, 06-21/10/2008

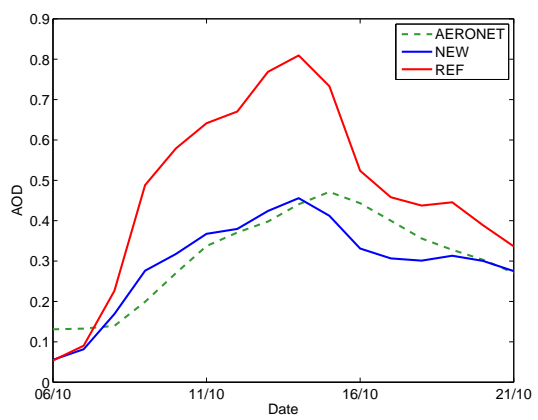

(c) Crete, 06/09-08/12 2008

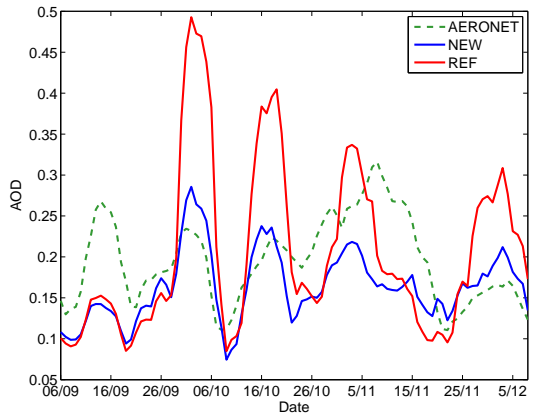

Fig. 7. Comparisons of AOD at $550 \mathrm{~nm}$ between AERONET measurements and REF (red line) and NEW (blue line) experiments at three different locations: Blida (a), Barcelona (b) and Crete (c). Time series of AOD values (dashed green lines) represent seven-day-averaged daily values.

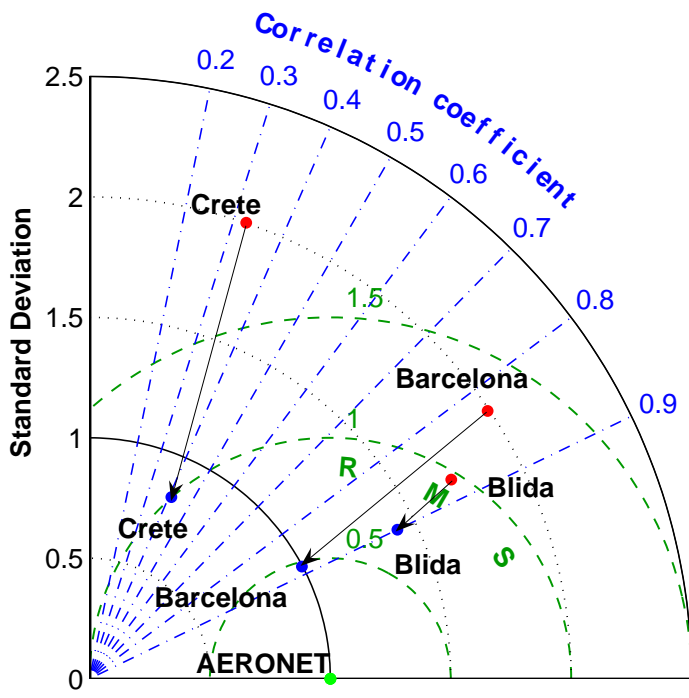

Fig. 8. Taylor diagram representing the correlation in time between observations (AERONET data presented in Fig. 7) and RegCM-4 simulations of the AOD. Red points: REF, blue points: NEW, green point: MODIS.

\section{Results: impact at the seasonal scale}

\subsection{Comparison of simulations with observations in 2008}

This section compares AOD simulations with MODIS data for the four seasons of the year 2008. The atmospheric aerosol content follows a seasonal cycle, strongly influenced by dust transport (Moulin et al., 1998). Figure 9 shows the results in winter (on the left, DJF: December-JanuaryFebruary), and in spring (on the right, MAM: MarchApril-May). The AOD over the Mediterranean Sea is small in winter because heavy rainfall and strong wind prevent aerosols from accumulating in the domain atmosphere. AOD at $550 \mathrm{~nm}$ reaches about 0.1 to 0.2 from west to east over the sea. These values are similar in both simulations, but with a slight underestimation especially in REF in the Eastern Mediterranean. The average difference with MODIS over the sea is -0.019 for REF and only -0.007 for NEW. Over Northern Africa, AOD is clearly overestimated in Algeria, with a bias reaching 0.27 compared to Deep Blue data, reduced in 0.14 in NEW. The underestimation between 20 and $25^{\circ} \mathrm{E}$ by REF is also corrected by NEW.

In spring, dust begins transport over the sea increases because of changing circulation pattern (Gkikas et al., 2012) and intense dust uplift over the Libyan and Egyptian deserts (Moulin et al., 1998), thereby increasing the AOD. For this period, the satellite data show a contrast between the Western and Eastern Mediterranean Sea. This contrast is well represented by both simulations, with a maximum along the Libyan coast. As far as the Saharan desert is concerned, what is striking is the overestimation by REF of the dust emission in Algeria and Tunisia (between 0.4 and 0.8 at $550 \mathrm{~nm}$ ) compared to Deep Blue data (between 0.3 and 0.6). The NEW simulation performs better, with AOD ranging from 0.3 to 0.6 too. We can also notice local maxima, for example in northeastern Algeria, where AOD at $550 \mathrm{~nm}$ reaches 0.55 both in MODIS and NEW. Over the Mediterranean Sea, the average difference with MODIS AOD is reduced from 0.043 in REF to 0.017 in NEW. However, a problem remains over Near East, as MODIS AOD is around 0.9 whereas RegCM-4 simulations are around 0.4. This may be due to dust advection from eastern regions, which are not taken into account in our domain.

Figure 10 presents the comparison between MODIS and RegCM-4 for summer (JJA: June-July-August) on the left, and for autumn (SON: September-October-November) on the right. Over the Mediterranean Sea, summer AOD ranges from 0.2 to 0.4 according to MODIS data, with a maximum along the northwestern African coast. This maximum is in good agreement with both RegCM-4 simulations, although it is too widespread in REF around Sicilia, giving a maximal difference over the sea with MODIS of 0.12 instead 
DJF
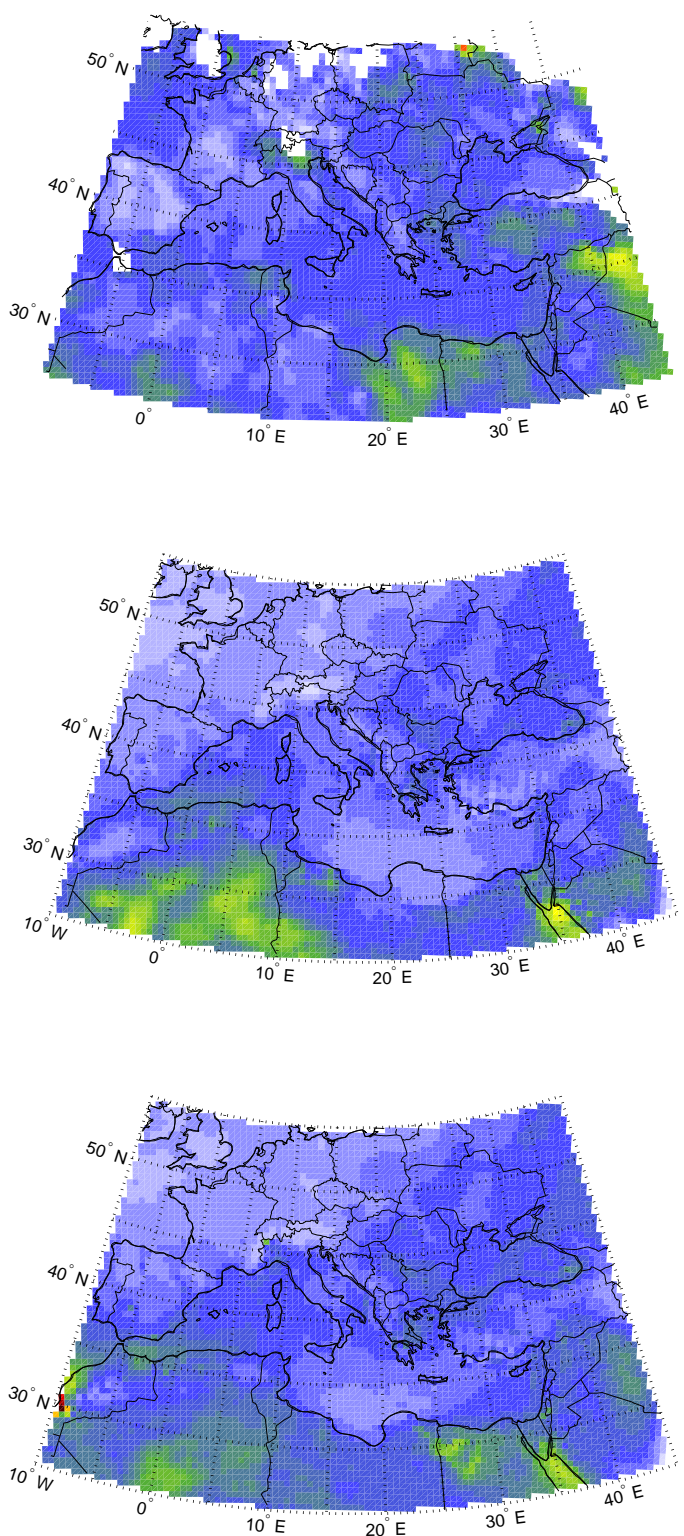

MAM

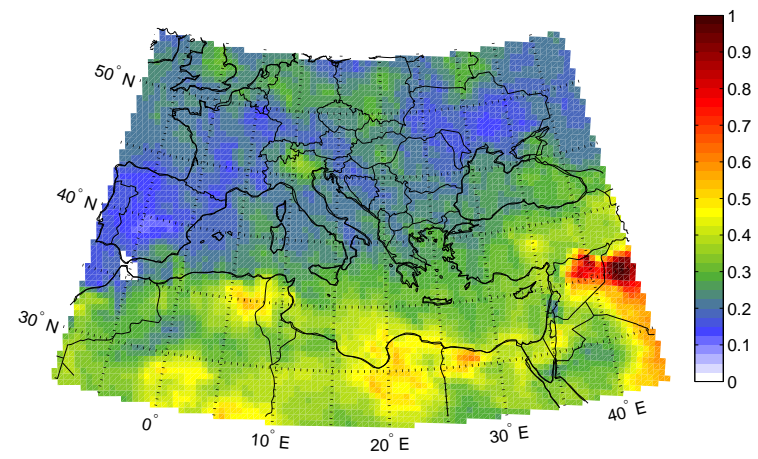

$\frac{3}{2}$

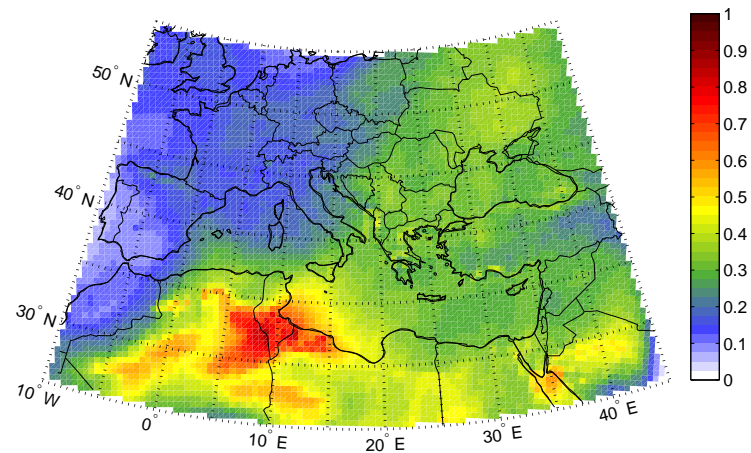

$\frac{\pi}{T}$

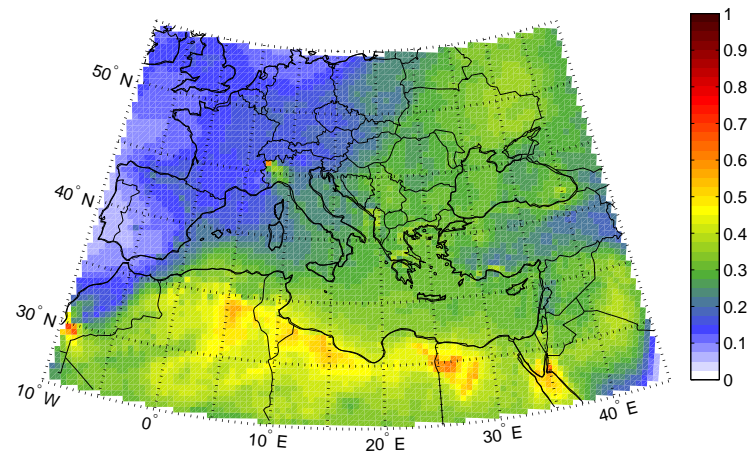

Longitude $\left(^{\circ}\right)$

Fig. 9. Comparison of aerosol optical depth (AOD) at $550 \mathrm{~nm}$ between MODIS data (top panels), REF-experiment (middle panels) and NEW-experiment (bottom panels) in winter (December-January-February) 2008 (on the left) and in spring (March-April-May) 2008 (on the right).

of 0.06 for NEW. In Northern Africa, AOD is well simulated in western Algeria, but the maximum seen in Deep Blue data over Northern Tunisia is not represented by RegCM-4. We can also notice an underestimation of AOD by REF in Egypt $\left(0.15\right.$ around $\left.30^{\circ} \mathrm{E}\right)$, which is corrected in the NEW simulation (0.3), reducing the average bias over the Northern African continent from -0.091 in REF to -0.055 in NEW. In some regions, REF also underestimates AOD, due for example to inaccurate soil properties, leading to an unrealistic distribution amongst the bins, possibly corrected in the NEW approach. Spatial AOD gradients over the sea are also improved in the NEW simulation, particularly along the North African coast. The problem of underestimation of the simulated AOD in the Near East is still present.

Compared to summer, autumnal AOD values over the sea are smaller according to Fig. 10, ranging from 0.15 

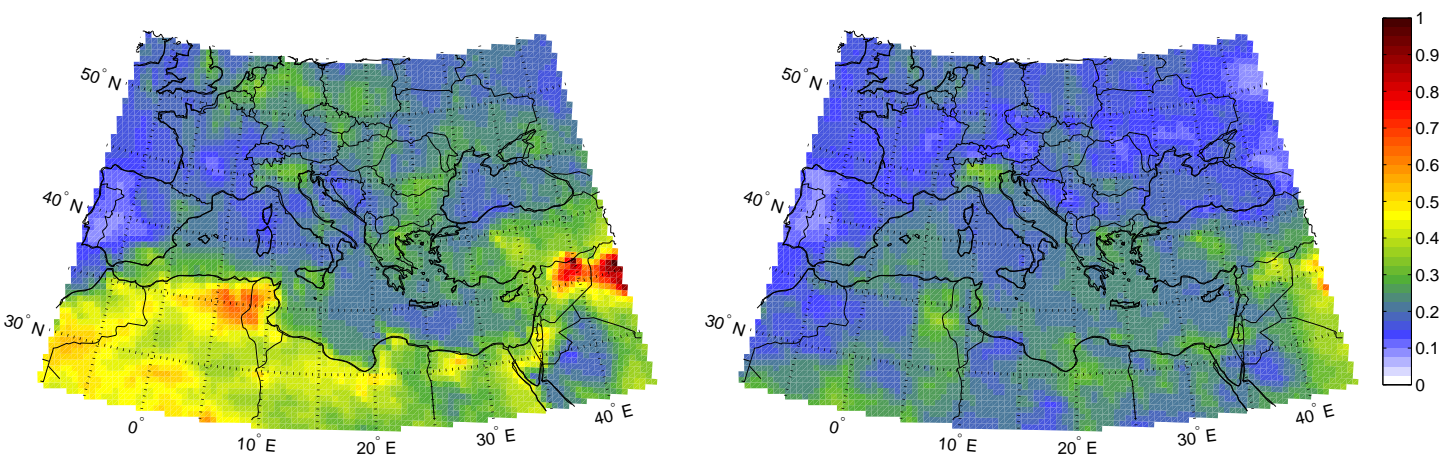

$\frac{3}{3}$
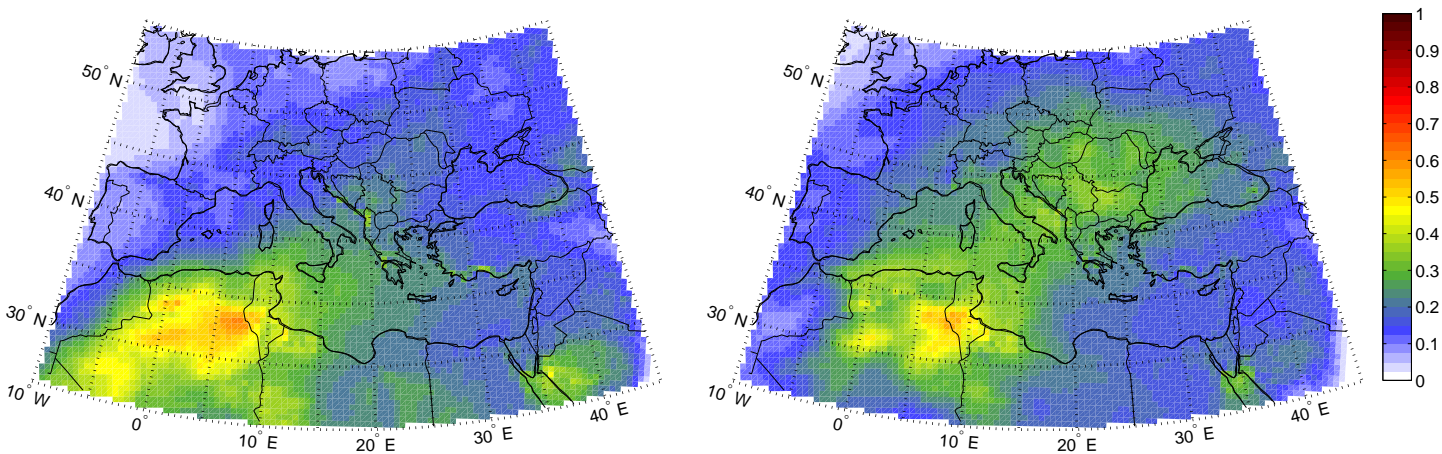

$\frac{\pi}{\pi}$
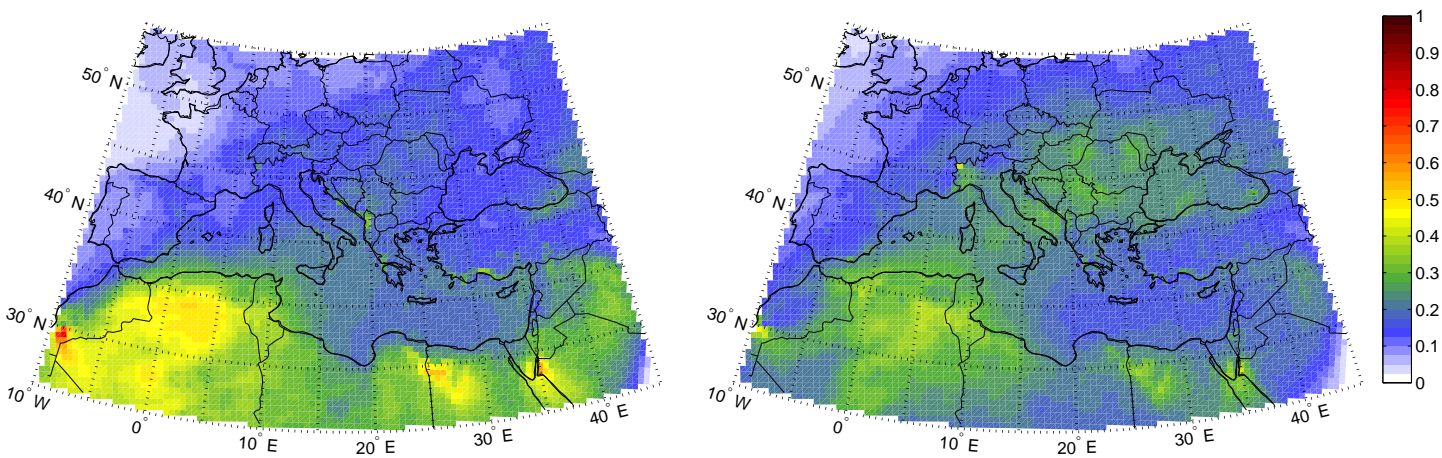

Longitude $\left(^{\circ}\right)$

Fig. 10. Comparison of aerosol optical depth (AOD) at $550 \mathrm{~nm}$ between MODIS data (top panels), REF-experiment (middle panels) and NEW-experiment (bottom panels) in summer (June-July-August) 2008 (on the left) and in autumn (September-October-November) 2008 (on the right).

to 0.35 in MODIS data. The maximum along the northwestern African coast is still observed, but is not as well represented in RegCM-4 simulations as for the summer. Indeed, it is too widespread, especially in REF whose AOD values are about 0.1 higher than in NEW. The average difference over the sea with MODIS is indeed 0.023 for REF, improving to -0.010 for NEW. Over Africa, Deep Blue data and the NEW simulation are in good agreement with values ranging from 0.2 to 0.35 . In REF, AOD is out of this range in Tunisia (0.5) and in Egypt (0.15).

In brief, Figs. 9 and 10 indicate that the new dust particle size distribution in the NEW simulation produces a significant improvement in the simulated AOD. In particular, the observed spatial AOD gradient over the sea is generally better reproduced in the NEW simulation. The main cause of this difference between the REF and the NEW simulations is 
the different predicted mass fractions for the first dust bin (0.01-1.0 $\mu \mathrm{m}$ diameter), which produces the largest massweighted effect on AOD (e.g. Tegen and Lacis, 1996). Since particles in this size range also have the longest lifetimes, a larger mass fraction of particles in this bin produces a smaller AOD spatial gradient. Similar to the results of the episodic dust outbreaks in the previous section, the mass fraction for the first bin in the REF parameterization is a factor of $\sim 5$ larger than for the NEW distribution, which consequently produces a weaker spatial AOD gradient. This effect is for example illustrated in the summer in the central Mediterranean (Fig. 10). The effect of the different size distribution on the simulated dust burden is presented in Fig. 11, with averages of every dust bin integrated concentration over the year 2008. With the REF scheme, the relative weight of the fine mode over the Saharan regions is clearly larger than for the NEW scheme. In contrast, with the new size distribution, the column burden of the larger dust $(>1.0 \mu \mathrm{m})$ is substantially increased, especially for the third dust bin $(2.5-5.0 \mu \mathrm{m}$ diameter). Since larger dust aerosols have greater fall speeds and are thus deposited earlier and closer to the source regions than smaller aerosols, this change in the size distribution over the Saharan source regions affects the size distribution of dust transported over the Mediterranean Sea. This effect is clearly seen in Fig. 11: the smallest particle bin dominates the REF column burden over the Mediterranean Sea, whereas the larger particle bins dominate the NEW column burden.

In conclusion, we can deduce from these comparisons, between satellite data, in-situ observations and RegCM-4 simulations, that dust emissions are better simulated with the new dust size distribution. In particular, this new scheme has corrected some inaccurate AOD estimations in the REF parameterization over the Mediterranean region. This improvement is confirmed by the corresponding Taylor diagram in Fig. 12. For each season, the blue point representing the NEW-experiment is closer to the MODIS observation (in green) than the red point representing the REF-experiment. This indicates that the new dust scheme reduces the simulation error. Other sources of error include inaccuracies in simulated soil properties (roughness and texture), surface wind, or anthropogenic aerosols, which can explain why the correlation coefficient is not so high. In this set of simulations, a deeper analysis shows that RegCM-4 actually underestimates the anthropogenic sulfates over Europe in summer. Moreover, secondary organic as well as nitrate aerosol components are not included in these simulations. Since our purpose here is clearly to discuss the dust component, we do not analyse further the contribution of these other aerosol types.

\subsection{Impact on the aerosol content and direct radiative forcing with a decadal simulation}

Since the new size distribution has substantially improved the simulations at the seasonal scale over our region, we use it to estimate the potential impact of dust aerosols on the Mediterranean climate. The direct and semi-direct effects of aerosols on climate are caused by their influence on SW and LW radiation. In order to better assess the resulting radiative forcing, a longer simulation, namely NEW 2000-2009, has been performed over the period 2000-2009.

This ten-year simulation enables us to elaborate on the seasonal cycle of aerosols over the Mediterranean region. Figure 13a presents the monthly means of AOD over Northern Africa (from $25^{\circ} \mathrm{N}$ to the sea), the Mediterranean Sea and Southern Europe (from the sea to $47.5^{\circ} \mathrm{N}$ ) for REF 2008, NEW 2008 and NEW 2000-2009 simulations. The interannual variability is assessed with a $95 \%$ confidence interval around the average. The AOD cycle is consistent with Figs. 9 and 10 shown in Sect. 5.1, which also show an overestimation in the REF simulation of AOD in spring and autumn. Compared to the average 2000/2009, AOD for the reference year 2008 is close to this average, and is included for most of months in the $95 \%$ confidence interval (except October notably). The main maximum of AOD occurs in spring, when dust is transported from the Eastern Sahara to the Eastern Mediterranean. In summer, this phenomenon moves to the Western Mediterranean, with a second maximum in September. Indeed, the aerosol episodes are most frequently observed during the dry period, from June to October (Gkikas et al., 2012). In contrast, AOD is minimal in winter. This variation is related to synoptic meteorological conditions. During the dry period, namely from June to October, the synoptic conditions prevailing over the Mediterranean favour the accumulation of aerosol particles in the atmosphere. Specifically, during this period, the subtropical Atlantic high (Azores) prevails over the Mediterranean basin, being enhanced and causing subsidence. It results thus in an extremely stable atmosphere and in absence of rainfall, conditions that favour the aerosol accumulation in the atmosphere.

Figure $13 \mathrm{~b}$ and $\mathrm{c}$ present the monthly-averaged radiative forcing (RF), respectively, at the surface and at the top of the atmosphere (TOA) for LW and SW radiation, and Fig. 14 presents the corresponding maps for the NEW 2000-2009 simulation. Table 3 summarizes their annual and seasonal averages over Northern Africa, the Mediterranean Sea and Southern Europe. With the new emitted dust size distribution, RF has been significantly modified. The surface SW RF is negative on the whole domain, but the strongest values (up to $-22 \mathrm{~W} \mathrm{~m}^{-2}$ ) are observed in spring in dust-emitting regions and over the sea near the coast, with a north-south gradient. Indeed, dust prevents the Sun's radiation from reaching the surface, producing a dimming and a cooling (direct) effect. This maximum in shortwave direct effect is coherent with the study of Benas et al. (2011) in Crete. Over the period 20002010, calculations performed with a radiation transfer model based on Terra and Aqua MODIS data has shown a similar seasonal cycle, despite a stronger aerosol direct radiative forcing over Crete $\left(-26 \pm 16 \mathrm{~W} \mathrm{~m}^{-2}\right.$ against $-13 \mathrm{~W} \mathrm{~m}^{-2}$ for 


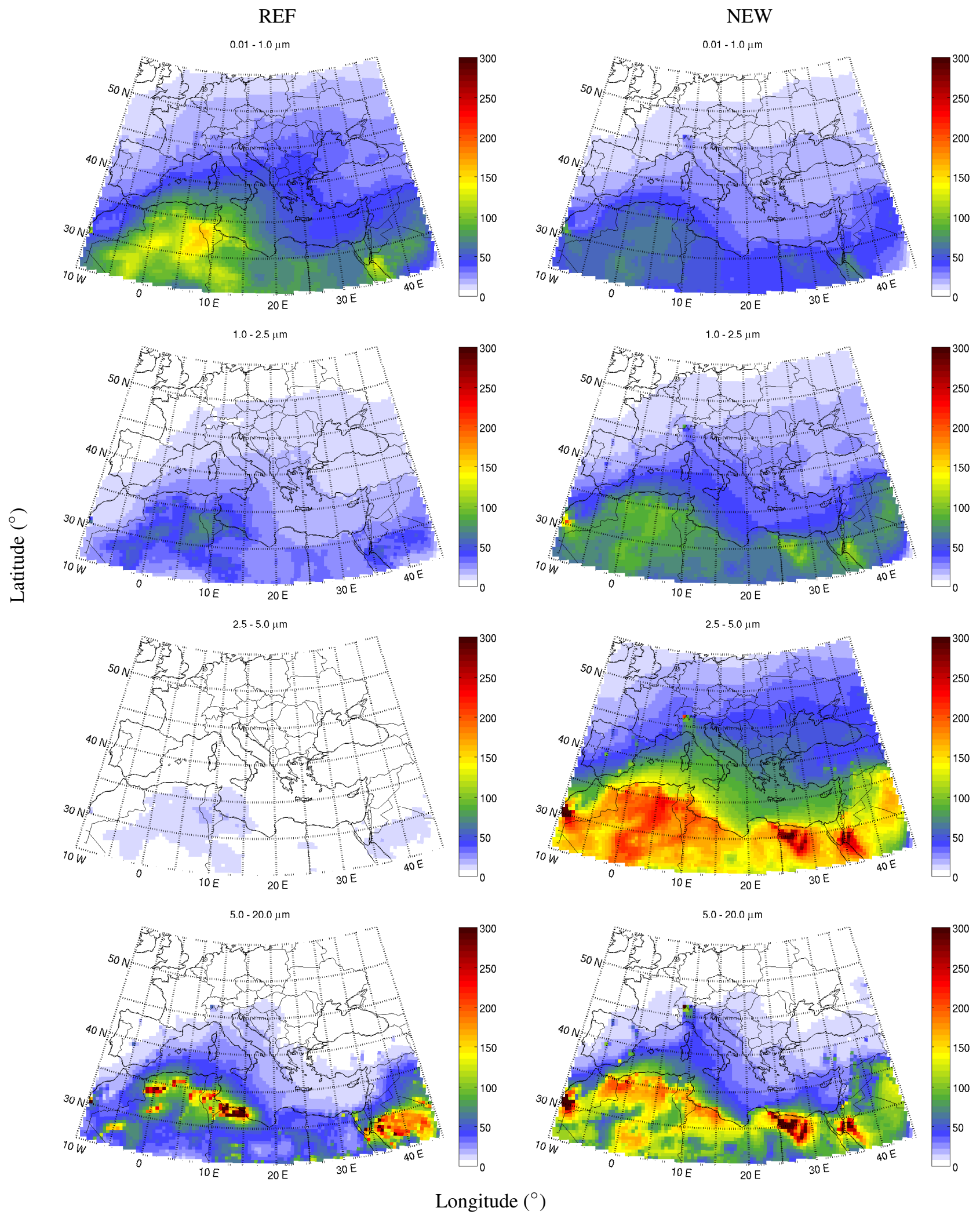

Fig. 11. Dust integrated concentration over an atmospheric column $\left(\mathrm{mg} \mathrm{m}^{-2}\right)$ for REF (left panels) and NEW (right panels) experiments over the year 2008 for each of the four bins of RegCM-4. 
Table 3. Annual (first line of each cell) SW and LW direct radiative forcing averages $\left(\mathrm{W} \mathrm{m}^{-2}\right)$ at the surface and TOA for the NEW simulation over Northern Africa (from $25^{\circ} \mathrm{N}$ to the sea), the Mediterranean Sea and Southern Europe (from the sea to $47.5^{\circ} \mathrm{N}$ ). Seasonal averages (DJF/MAM/JJA/SON) are indicated on the second line of each cell for the same regions and parameters.

\begin{tabular}{ccccc}
\hline \multicolumn{2}{c}{ RF } & Northern Africa & Mediterranean Sea & Southern Europe \\
\hline \multirow{3}{*}{ SW } & Surface & -14.9 & -13.6 & -10.3 \\
& & $(-9.7 /-20.2 /-18.5 /-11.4)$ & $(-7.9 /-19.5 /-15.3 /-11.5)$ & $(-5.8 /-13.6 /-12.4 /-9.2)$ \\
& TOA & 0.1 & -5.5 & -3.1 \\
& & $(-1.1 / 0.7 / 1.2 /-0.6)$ & $(-3.8 /-8.2 /-5.5 /-4.7)$ & $(-2.3 /-4.6 /-2.5 /-3.0)$ \\
\hline \multirow{4}{*}{ SW } & \multirow{2}{*}{ Surface } & $(4.2 / 8.6 / 6.5 / 4.1)$ & 1.7 & 0.8 \\
& & 1.0 & $(1.1 / 3.1 / 1.3 / 1.3)$ & $(0.5 / 1.2 / 0.7 / 0.7)$ \\
& TOA & $(0.3 / 1.5 / 1.6 / 0.6)$ & 0.6 & 0.3 \\
& & & $(0.4 / 1.0 / 0.5 / 0.4)$ & $(0.1 / 0.6 / 0.3 / 0.2)$ \\
\hline
\end{tabular}

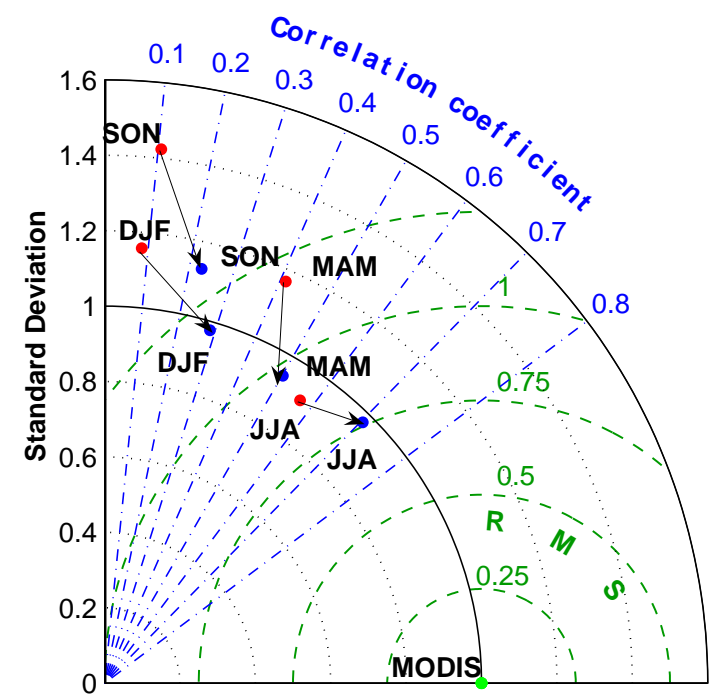

Fig. 12. Taylor diagram of seasonal averaged AOD $(550 \mathrm{~nm})$ computed with MODIS observation, REF and NEW experiments. Red points: REF, blue points: NEW, green point: MODIS.

RegCM-4) probably due to the lack of sulfate aerosols in RegCM-4 (see Sect. 5.1). At the TOA, the SW RF is also negative except in Northern Africa where it is slightly positive because of a high surface albedo in this region, enhancing absorption of reflected radiation. The LW RF is positive everywhere both at the surface and at TOA, but stronger at the surface since dust is essentially present in the lower troposphere.

With the new distribution (NEW), the LW RF has increased over Africa because of the presence of more coarse dust aerosols. Altogether, the annual-averaged surface RF is negative on the whole domain, with the highest values located along the North African coast (up to $-15 \mathrm{~W} \mathrm{~m}^{-2}$ ). It is stronger in spring, where monthly mean reaches $-20 \mathrm{~W} \mathrm{~m}^{-2}$ in April and May in NEW 2000/2009 over the Mediterranean Sea. At TOA, RF remains positive only on the African continent. To sum up, the SW RF is the most negative over the Mediterranean Sea because of the influence of both dust from Africa and anthropogenic particles from the continent and a lower surface albedo. These values are in quite good agreement with SW aerosol radiative forcing from the article of Papadimas et al. (2012), calculated with a spectral radiative transfer model from MODIS Terra (collection 5 and 5.1) Level-3 data. In the latter study, the direct SW radiative effect over the broader Mediterranean basin $\left(29-46.5^{\circ} \mathrm{N}\right.$, $10.5^{\circ} \mathrm{W}-38.5^{\circ} \mathrm{E}$ ) over the period 2000-2007 is estimated at the surface between $-5 \mathrm{~W} \mathrm{~m}^{-2}$ in winter and $-20 \mathrm{~W} \mathrm{~m}^{-2}$ in spring and summer, close to the variations simulated in NEW 2000/2009. The difference in summer probably comes from the lack of anthropogenic sulfates discussed in Sect. 5.1. With regards to the TOA, the SW RF is estimated between $-1 \mathrm{~W} \mathrm{~m}^{-2}$ in winter and $-4 \mathrm{~W} \mathrm{~m}^{-2}$ in summer in MODIS data, slightly higher than in the NEW 2000/2009 simulation. For the investigated year 2008, the changes observed at the TOA and at the surface for the SW RF show an improvement in the simulation of RF by RegCM-4. Over Northern Africa, the TOA SW RF is close to zero for the summer months for the NEW 2008 and 2000/2009 simulations, which agrees with satellite observations (Patadia et al., 2009; Yang et al., 2009). In contrast, the REF simulation produces too much TOA radiative cooling over the Sahara desert in comparison with these satellite observations. This is consistent with the larger mass fraction of fine dust in REF, which tends to produce a net cooling effect at TOA (Kok, 2011a).

\subsection{Impact on the deposition with a decadal simulation}

Dust aerosols also play an important role by depositing micronutrients to the Mediterranean Sea (Guieu et al., 2002). Indeed, dust contains iron which is an essential micronutrient for ocean biota growth (Mahowald et al., 2009) and can affect the productivity of marine and terrestrial ecosystems. The carbon cycle and therefore the atmospheric greenhouse gas content could also be influenced. Figure 13d presents the dry and wet deposition of dust aerosols for the three simulations. 

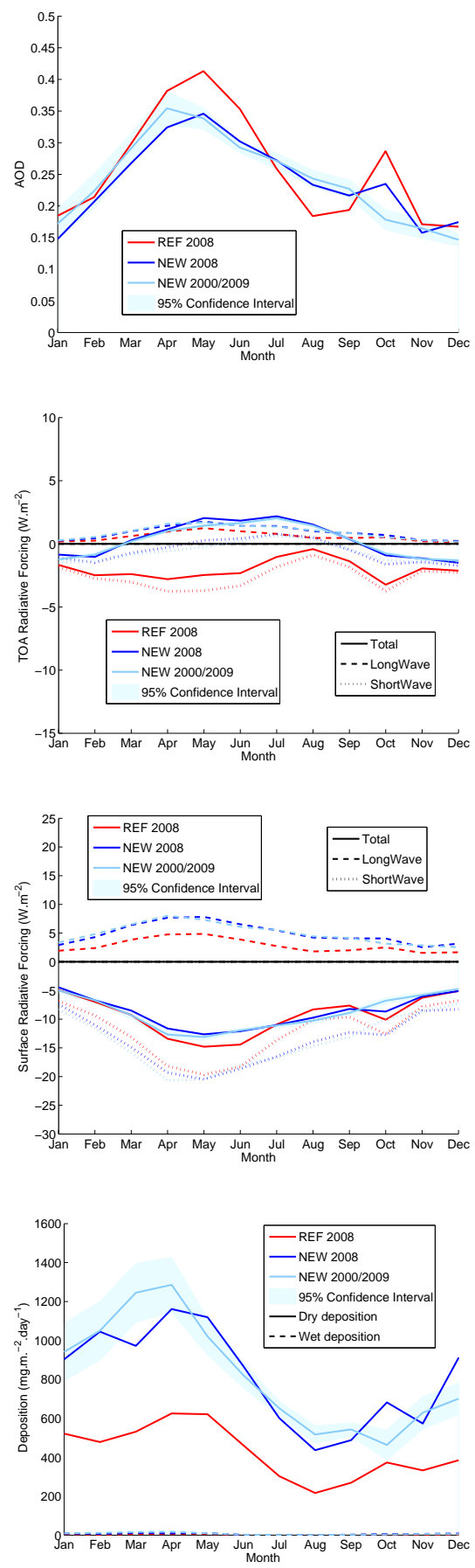

Northern Africa

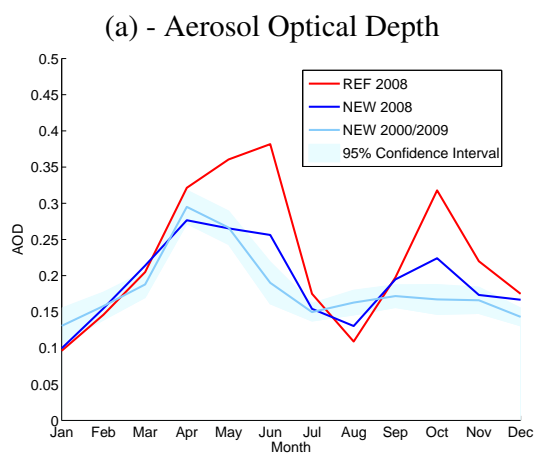

(b) - TOA Radiative Forcing

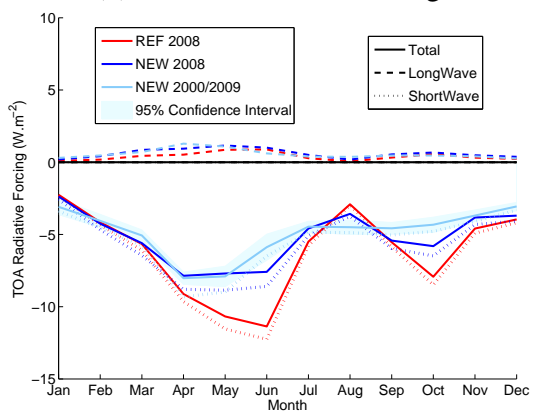

(c) - Surface Radiative Forcing

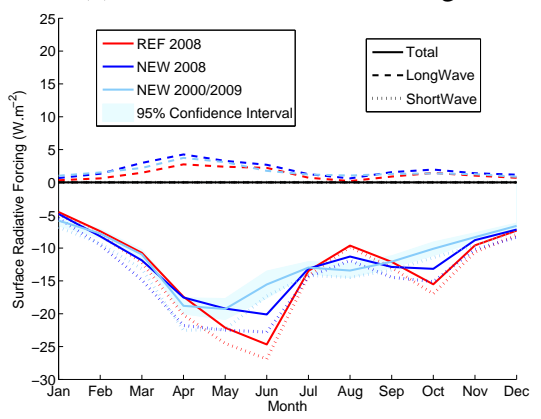

(d) - Dust deposition

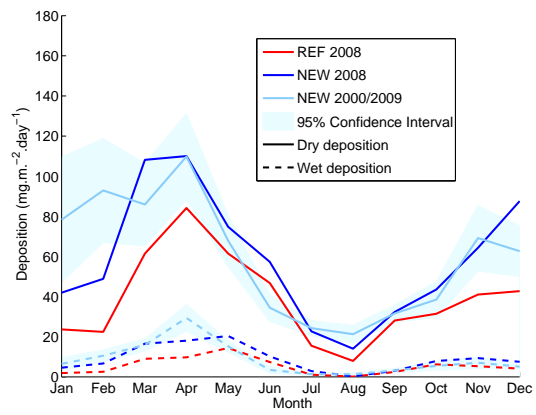

Mediterranean Sea
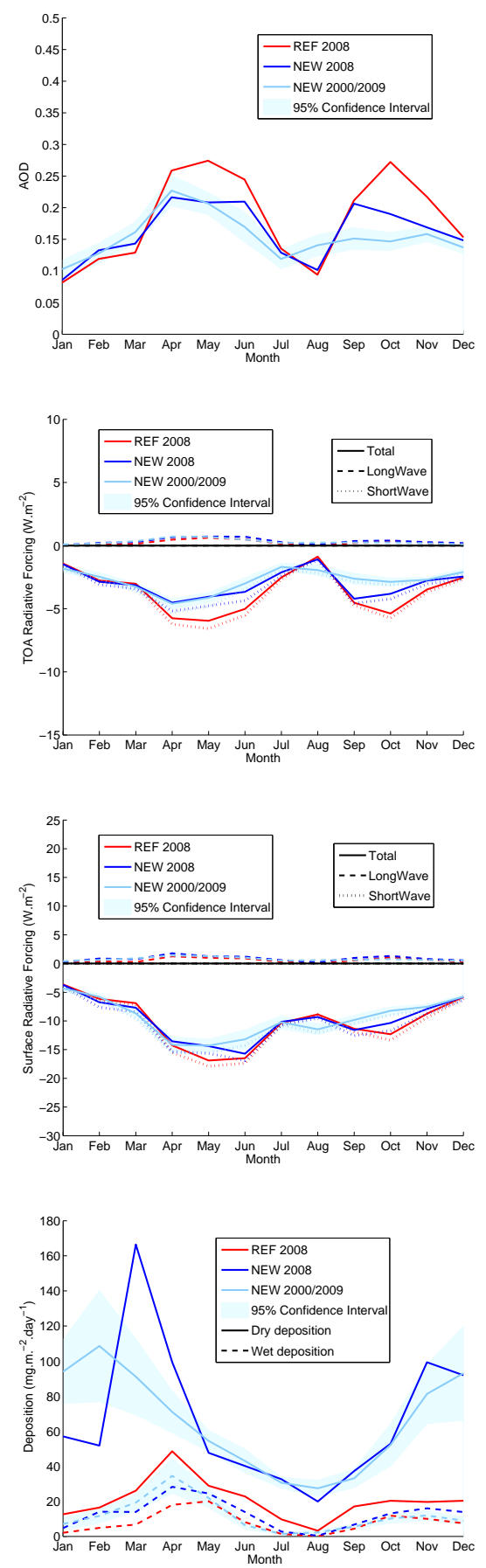

Southern Europe

Fig. 13. Monthly means of different parameters (aerosol optical depth at $550 \mathrm{~nm}$, TOA and surface radiative forcing, dry and wet deposition) for three simulations: REF (red) and NEW (blue) in 2008, and NEW 2000-2009 (light blue). Means are calculated over three regions: Northern Africa (left panels), the Mediterranean Sea (middle panels) and Southern Europe (right panels).

Since REF produces more fine dust aerosols, which can stay longer in the atmosphere and deposit further from source regions, deposition is smaller than in NEW. This effect increases dust deposition to the Mediterranean Sea by on average $57 \%$ over the year 2008 , and could affect directly the productivity of marine and terrestrial ecosystems. A similar increase in deposition rate with the theoretical size distribution of Kok (2011a) relative to empirical size distributions with larger mass fractions of fine dust was found in the recent global modeling study of Ito et al. (2012). Changes in the 
Surface
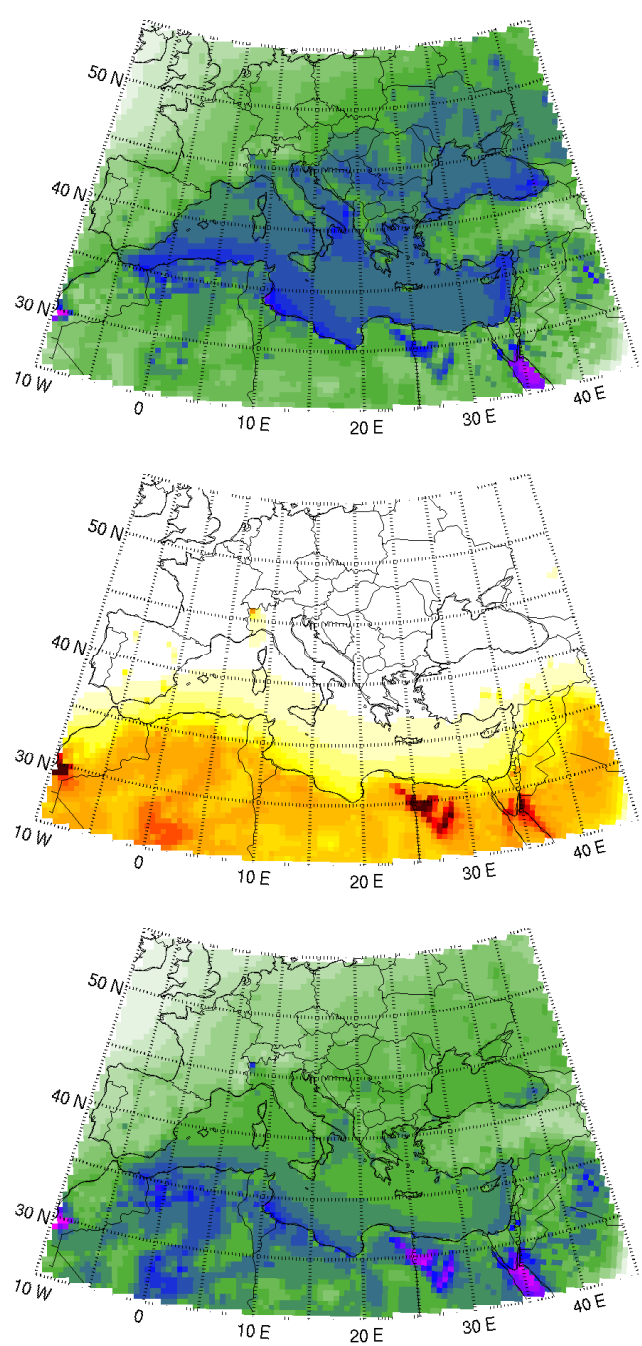
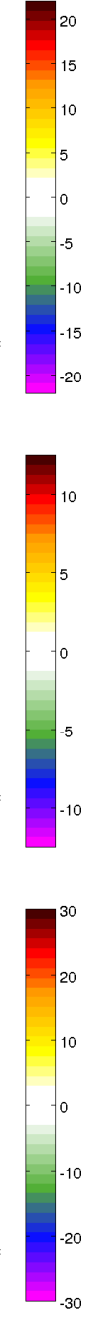

Longitude $\left(^{\circ}\right)$
TOA
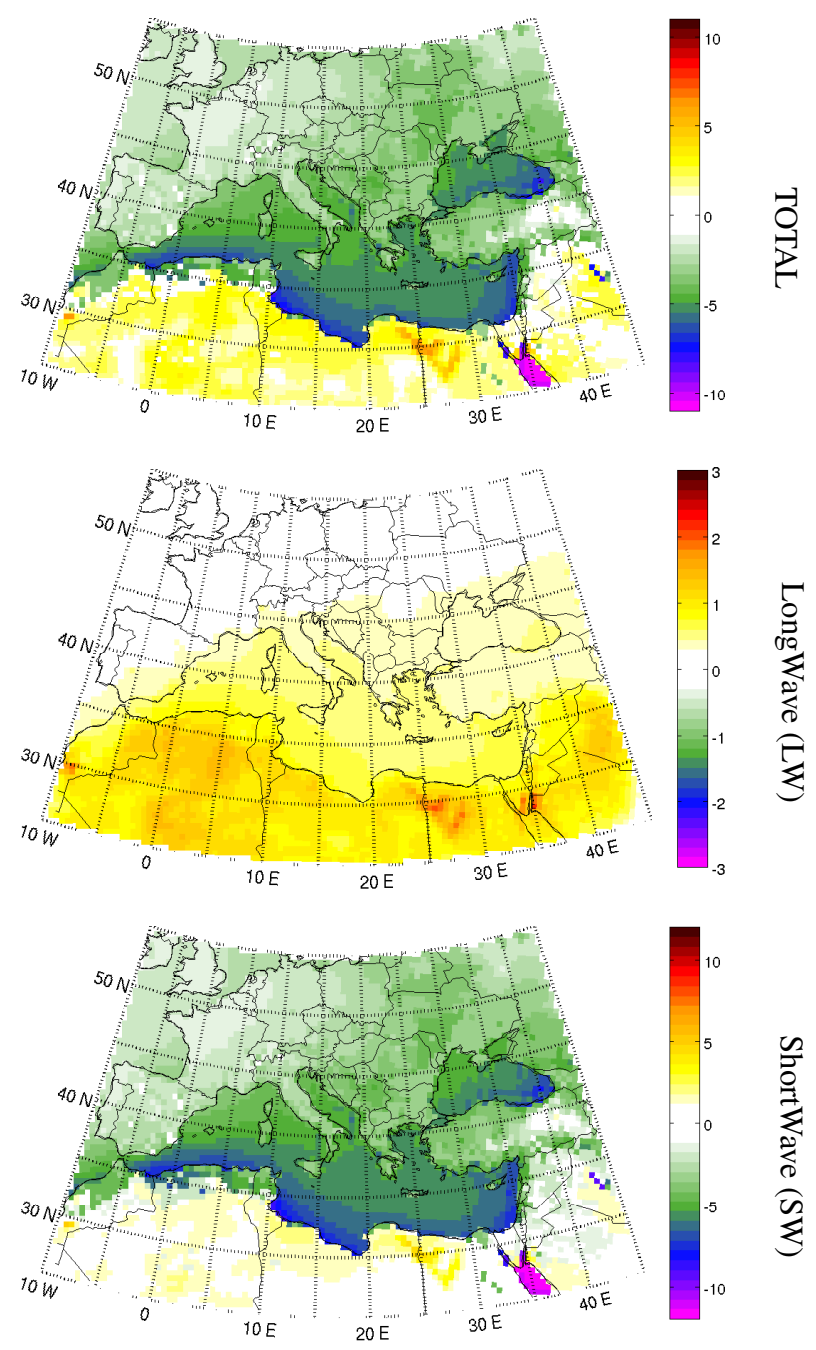

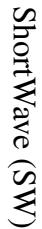

Fig. 14. Direct radiative forcing (in $\mathrm{W} \mathrm{m}^{-2}$ ) simulated in NEW 2000-2009, at the surface (left panels) and at the top of the atmosphere (TOA, right panels), for total (top panels), longwave (middle panels) and shortwave (bottom panels) radiations.

dust size distribution could also change the bioavailable iron fraction (Ito et al., 2012), which depends on the deposited dust size (Mahowald et al., 2009).

With regards to dry deposition, the longer simulation shows a large $95 \%$ confidence interval, indicating an important interannual variability. Its seasonal cycle is regulated by the aerosol content and the winds. The highest deposition values occur during the first four months of the year; because of the circulation in winter associated with stronger winds and higher precipitation, the residence time of aerosols is more important in summer than in winter. The role of winds is particularly important in Southern Europe, where the maximum is earlier (February) than in Africa and over the sea (April). Besides, a secondary maximum in autumn can be noticed in Africa in September, and over the Mediterranean
Sea in late autumn (November). This secondary maximum seems consistent with the dust episodes in autumn and the respective maximum of the wet deposition. In Africa, dry deposition is ten times higher than in Southern Europe and over the sea. On the contrary, wet deposition is very weak in this region because of the quasi-absence of rainfall. Over the sea and the European continent, wet deposition is maximum at the end of the wet season (April) in the Eastern basin, when rain is still important, and dust begins to be lifted and transported over the sea. A second maximum occurs in November. 


\section{Conclusions}

The effect of two dust particle size distribution schemes on the simulated dust cycle over the Mediterranean region have been compared by using the regional climate model RegCM4 to simulate both episodic dust outbreaks over the Mediterranean Sea and the seasonal dust cycle over the basin. The REF simulation with the initial scheme by Alfaro and Gomes (2001) produces a large mass fraction of emitted fine dust aerosols, causing errors in the spatial distribution of dust, as inferred from the spatial gradient of AOD, and therefore in the radiative budget. These problems were alleviated in the NEW simulation that uses a recent dust size distribution scheme based on the analogy of dust emission with the fragmentation of brittle materials (Kok, 2011a). In both studied episodic dust outbreak cases, the AOD simulated in REF is too large compared to MODIS data, whereas NEW shows more realistic values. Indeed, REF produces too many fine aerosols, which have a strong impact on SW radiation and can be easily transported to remote regions. In contrast, NEW simulated more coarse dust aerosols. This AOD overestimation by the REF simulation has been confirmed using observations from the AERONET network. With regards to seasonal means over the year 2008, AOD spatial gradients are also better estimated over the sea in the NEW simulation due to more coarse and fewer fine dust aerosols compared to REF. The average bias in spring over the Mediterranean Sea compared to MODIS AOD has been reduced from 0.043 in REF to 0.017 in NEW. Since a substantial improvement has been found compared to satellite and in-situ observations, as quantified using Taylor diagrams, this study has validated the use of the theoretical dust size distribution of Kok (2011a) in RegCM-4 at both event and seasonal time scales.

A longer simulation (over the period 2000-2009) has also been carried out with the new size distribution in order to better assess the radiative forcing due to aerosols. Dust aerosols prevail over the Mediterranean region, so that the surface SW RF is negative (direct effect), with maximal values in spring along the North African coast. The average SW RF over the Mediterranean Sea reaches $-13.6 \mathrm{~W} \mathrm{~m}^{-2}$ at the surface, and $-5.5 \mathrm{~W} \mathrm{~m}^{-2}$ at TOA. The LW RF is positive over the basin: $1.7 \mathrm{~W} \mathrm{~m}^{-2}$ on average over the Mediterranean Sea at the surface, and $0.6 \mathrm{~W} \mathrm{~m}^{-2}$ at TOA. It is stronger at the surface than at TOA, notably over Northern Africa (5.8 against $1.0 \mathrm{~W} \mathrm{~m}^{-2}$ ) because of the presence of dust aerosols in the lower troposphere. With regards to deposition, its seasonal cycle is controlled by the aerosol atmospheric content and the winds. Dry deposition is more important than wet deposition close to dust sources, and is stronger in winter. The new dust emitted size distribution has increased dry deposition by $57 \%$ on average over the year 2008 because of the emission of more coarse dust aerosols.

This study has focused on the Mediterranean basin so that the improvement shown in RegCM-4 with the new emitted dust size distribution has only been proved over this region. More studies should now be carried out to evaluate the impact of this new distribution over other dusty regions. It should also be noted that other parameters such as dust optical properties play an important role. In order to carry out studies to validate simulated dust deposition, the ChArMEx project (Chemical Aerosol Mediterranean Experiment, http://charmex.lsce.ipsl.fr/) will also help in providing more measurements in the following years.

As far as the impact of aerosols on climate is concerned, this study is limited by the fact that RegCM-4 has no twoway interaction between atmosphere and oceans, despite the potential importance of ocean evaporation. The ideal solution would be to resort to a coupled model (Somot et al., 2008), in order to take into account the role of SST notably, which has been found to be very influential on simulated dust-induced climate change (Yue et al., 2011). This study has shown an extra cooling simulated with the SST responses to dust forcing at the global scale $(-0.09 \mathrm{~K}$ in surface air temperature on average with interactive SSTs instead of $+0.02 \mathrm{~K}$ with prescribed SSTs).

Acknowledgements. MODIS data used in this paper were produced with the Giovanni online data system, developed and maintained by the NASA GES DISC. CALIOP data were obtained from the NASA Langley Research Center Atmospheric Science Data Center. Some of this work is supported by the National Science Foundation under Award AGS 1137716.

Edited by: C. Mitsakou

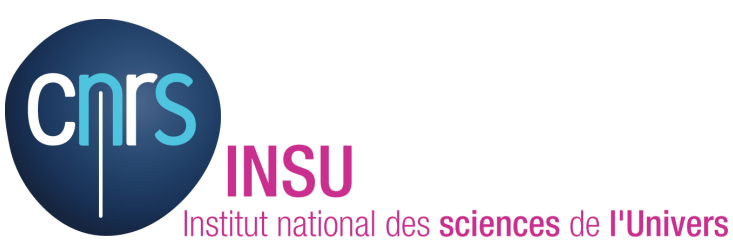

The publication of this article is financed by CNRS-INSU.

\section{References}

Alfaro, S. C. and Gomes, L.: Modeling mineral aerosol production by wind erosion: Emission intensities and aerosol size distribution in source areas, J. Geophys. Res., 106, 18075-18084, doi:10.1029/2000JD900339, 2001.

Alfaro, S. C., Gaudichet, A., Gomes, L., and Maillé, M.: Modeling the size distribution of a soil aerosol produced by sandblasting, J. Geophys. Res., 102, 11239-11249, 1997.

Barnaba, F. and Gobbi, G. P.: Aerosol seasonal variability over the Mediterranean region and relative impact of maritime, continental and Saharan dust particles over the basin from MODIS data in the year 2001, Atmos. Chem. Phys., 4, 2367-2391, doi:10.5194/acp-4-2367-2004, 2004. 
Basart, S., Pérez, C., Cuevas, E., Baldasano, J. M., and Gobbi, G. P.: Aerosol characterization in Northern Africa, Northeastern Atlantic, Mediterranean Basin and Middle East from direct-sun AERONET observations, Atmos. Chem. Phys., 9, 8265-8282, doi:10.5194/acp-9-8265-2009, 2009.

Benas, N., Hatzianastassiou, N., Matsoukas, C., Fotiadi, A., Mihalopoulos, N., and Vardavas, I.: Aerosol shortwave direct radiative effect and forcing based on MODIS Level 2 data in the Eastern Mediterranean (Crete), Atmos. Chem. Phys., 11, 1264712662, doi:10.5194/acp-11-12647-2011, 2011.

Bréon, F.-M., Vermeulen, A., and Descloitres, J.: An evaluation of satellite aerosol products against sunphotometers measurements, Remote Sens. Environ., 115, 3102-3111, doi:10.1016/j.rse.2011.06.017, 2011.

Colin, J., Déqué, M., Radu, R., and Somot, S.: Sensitivity study of heavy precipitation in Limited Area Model climate simulations: influence of the size of the domain and the use of the spectral nudging technique, Tellus A, 62, 591-604, 2010.

Crumeyrolle, S., Tulet, P., Gomes, L., Garcia-Carreras, L., Flamant, C., Parker, D. J., Matsuki, A., Formenti, P., and Schwarzenboeck, A.: Transport of dust particles from the Bodélé region to the monsoon layer - AMMA case study of the 9-14 June 2006 period, Atmos. Chem. Phys., 11, 479-494, doi:10.5194/acp-11479-2011, 2011.

de Madron, X. D., Guieu, C., Sempéré, R., Conan, P., Cossa, D., D’Ortenzio, F., Estournel, C., Gazeau, F., Rabouillem, C., Stemmann, L., Bonnet, S., Diaz, F., Koubbi, P., Radakovitch, O., Babin, M., Baklouti, M., Bancon-Montigny, C., Belviso, S., Bensoussan, N., Bonsangm, B., Bouloubassi, I., Brunet, C., Cadiou, J.-F., Carlotti, F., Chami, M., Charmasson, S., Charrière, B., Dachs, J., Doxaran, D., Dutay, J.-C., Elbaz-Poulichet, F., Eléaume, M., Eyrolles, F., Fernandez, C., Fowler, S., Francour, P., Gaertner, J., Galzin, R., Gasparini, S., Ghiglione, J.-F., Gonzalez, J.-L., Goyet, C., Guidi, L., Guizien, K., Heimbürger, L.E., Jacquet, S., Jeffrey, W., Joux, F., Hir, P. L., Leblanc, K., Lefèvre, D., Lemé R., Loye, M.-D., Pilot, Mallet, M., Méjanelle, L., Melin, F., Mellon, C., Mérigot, B., Merle, P.-L., Migon, C., Miller, W., Mortier, L., Mostajir, B., Mousseau, L., Moutin, T., Para, J., Perez, T., Petrenko, A., Poggiale, J.-C., Prieur, L., PujoPay, M., Pulido-Villena, Raimbault, P., Rees, A., Ridame, C., Rontani, J.-F., Pino, D. R., Sicrem, M., Taillandier, V., Tamburini, C., Tanaka, T., Taupier-Letage, I., Tedetti, M., Testor, P., Thébault, H., Thouvenin, B., Touratier, F., Tronczynski, J., Ulses, C., Wambeke, F. V., Vantrepotte, V., Vaz, S., and Verney, R.: Marine ecosystems' responses to climatic and anthropogenic forcings in the Mediterranean, Prog. Oceanogr., 91, 97166, doi:10.1016/j.pocean.2011.02.003, 2011.

Dee, D. P., Uppala, S. M., Simmons, A. J., Berrisford, P., Poli, P., Kobayashi, S., Andrae, U., Balmaseda, M. A., Balsamo, G., Bauer, P., Bechtold, P., Beljaars, A. C. M., van de Berg, L., Bidlot, J., Bormann, N., Delsol, C., Dragani, R., Fuentes, M., Geer, A. J., Haimbergere, L., Healy, S. B., Hersbach, H., Hólm, E. V., Isaksen, L., Kallberg, P., Köhler, M., Matricardi, M., McNally, A. P., Monge-Sanzf, B. M., Morcrette, J.-J., Park, B.-K., Peubey, C., de Rosnaya, P., Tavolato, C., Thépaut, J.-N., and Vitart, F.: The ERA-Interim reanalysis: configuration and performance of the data assimilation system, Q. Roy. Meteorol. Soc., 137, 553597, doi:10.1002/qj.828, 2011.
Dickinson, R. E., Errico, R. M., Giorgi, F., and Bates, G.: A regional climate model for the western United States, Climate Change, 15, 383-422, 1989.

Dickinson, R. E., Henderson-Sellers, A., and Kennedy, P. J.: Biosphere-atmosphere transfer scheme (bats) version 1e as coupled to the NCAR community climate model, Tech. rep., National Center for Atmospheric Research, Tech Note NCAR.TN387+STR, NCAR, Boulder, CO, 1993.

Dubovik, O. and King, M. D.: A flexible inversion algorithm for retrieval of aerosol optical properties from Sun and sky radiance measurements, J. Geophys. Res., 105, 20673-20696, doi:10.1029/2000JD900282, 2000.

Eck, T. F., Holben, B. N., Reid, J. S., Dubovik, O., Smirnov, A., O'Neill, N. T., Slutsker, I., and Kinne, S.: Wavelength dependence of the optical depth of biomass burning, urban, and desert dust aerosols, J. Geophys. Res., 104, 31333-31349, doi:10.1029/1999JD900923, 1999.

Emanuel, K. A.: A scheme for representing cumulus convection in large-scale models, J. Atmos. Sci., 48, 2313-2335, 1991.

Fécan, F., Marticorena, B., and Bergametti, G.: Parametrization of the increase of the aeolian erosion threshold wind friction velocity due to soil moisture for arid and semi-arid areas, Ann. Geophys., 17, 149-157, doi:10.1007/s00585-999-0149-7, 1999.

Gao, X., Pal, J. S., and Giorgi, F.: Projected changes in mean and extreme precipitation over the Mediterranean region from a high resolution double nested RCM simulation, Geophys. Res. Lett., 33, L03706, doi:10.1029/2005GL024954, 2006.

Gillette, D. A.: On the production of soil wind erosion having the potential for long range transport, Journal de Recherches Atmospheriques, 8, 734-744, 1974.

Gillette, D. A.: Environmental Factors Affecting Dust Emission by Wind Erosion, c. morales edn., John Wiley, New York, 1979.

Giorgi, F. and Lionello, P.: Climate change projections for the Mediterranean region, Global Planet. Change, 63, 90-104, doi:10.1016/j.gloplacha.2007.09.005, 2008.

Giorgi, F. and Mearns, L. O.: Introduction to special section: Regional climate modeling revisited, J. Geophys. Res., 104, 63356352, doi:10.1029/98JD02072, 1999.

Giorgi, F., Coppola, E., Solmon, F., Mariotti, L., Sylla, M. B., Bi, X., Elguindi, N., Diro, G. T., Nair, V., Giuliani, G., Cozzini, S., Guettler, I., O’Brien, T. A., Tawfik, A. B., Shalaby, A., Zakey, A. S., Steiner, A. L., Stordal, F., Sloan, L. C., and Brankovic, C.: RegCM4: model description and preliminary tests over multiple CORDEX domains, Clim. Res., 52, 7-29, doi:10.3354/cr01018, 2012.

Gkikas, A., Houssos, E., Hatzianastassiou, N., Papadimas, C., and Bartzokas, A.: Synoptic conditions favouring the occurrence of aerosol episodes over the broader Mediterranean basin, Q. J. Roy. Meteorol. Soc., 138, 932-949, doi:10.1002/qj.978, 2012.

Grell, G. A., Dudhia, J., and Stauffer, D. R.: A Description of the, fifth generation Penn State/MCAR Mesoscale Model (MM5), Tech. rep., National Center for Atmospheric Research, Tech Note NCAR/TN-398+STR, NCAR, Boulder, CO, 1994.

Guieu, C., Loye-Pilot, M. D., Ridame, C., and Thomas, C.: Chemical characterization of the Saharan dust end-member: Some biogeochemical implications for the western Mediterranean Sea, J. Geophys. Res., 107, 4258, doi:10.1029/2001JD000582, 2002. 
Herrmann, M., Somot, S., Calmanti, S., Dubois, C., and Sevault, F.: Representation of spatial and temporal variability of daily wind speed and of intense wind events over the Mediterranean Sea using dynamical downscaling: impact of the regional climate model configuration, Nat. Hazards Earth Syst. Sci., 11, 19832001, doi:10.5194/nhess-11-1983-2011, 2011.

Holben, B. N., Eck, T. F., Slutsker, I., Tanré, D., Buis, J. P., Setzer, A., Vermote, E., Reagan, J. A., Kaufman, Y., Nakajima, T., Lavenu, F., Jankowiak, I., and Smirnov, A.: AERONET-A Federated Instrument Network and Data Archive for Aerosol Characterization, Remote Sens. Environ., 66, 1-16, doi:10.1016/S00344257(98)00031-5, 1998

Holben, B. N., Tanré, D., Smirnov, A., Eck, T. F., Slutsker, I., Abuhassan, N., Newcomb, W. W., Schafer, J. S., Chatenet, B., Lavenu, F., Kaufman, Y. J., Castle, J. V., Setzer, A., Markham, B., Clark, D., Frouin, R., Halthore, R., Karneli, A., O’Neill, N. T., Pietras, C., Pinker, R. T., Voss, K., and Zibordi, G.: An emerging ground-based aerosol climatology: Aerosol optical depth from AERONET, J. Geophys. Res., 106, 12067-12097, doi:10.1029/2001JD900014, 2001.

Hsu, N. C., Tsay, S.-C., King, M., and Herman, J. R.: Aerosol properties over bright-reflecting source regions, IEEE T. Geosci. Remote, 42, 557-569, doi:10.1109/TGRS.2004.824067, 2004.

Huneeus, N., Schulz, M., Balkanski, Y., Griesfeller, J., Prospero, J., Kinne, S., Bauer, S., Boucher, O., Chin, M., Dentener, F., Diehl, T., Easter, R., Fillmore, D., Ghan, S., Ginoux, P., Grini, A., Horowitz, L., Koch, D., Krol, M. C., Landing, W., Liu, X., Mahowald, N., Miller, R., Morcrette, J.-J., Myhre, G., Penner, J., Perlwitz, J., Stier, P., Takemura, T., and Zender, C. S.: Global dust model intercomparison in AeroCom phase I, Atmos. Chem. Phys., 11, 7781-7816, doi:10.5194/acp-11-7781-2011, 2011.

IPCC: Climate Change 2007: Synthesis Report, Contribution of Working Groups I, II and III to the Fourth Assessment Report of the Intergovernmental Panel on Climate Change, IPCC, Geneva, Switzerland, core writing team, pachauri, a. Edn., r.k and reisinger, 2007.

Israelevich, P., Ganor, E., Alpert, P., Kishcha, P., and Stupp, A.: Predominant transport paths of Saharan dust over the Mediterranean Sea to Europe, J. Geophys. Res., 117, D02205, doi:10.1029/2011JD016482, 2012.

Ito, A., Kok, J. F., Feng, Y., and Penner, J. E.: Does a theoretical estimation of the dust size distribution at emission suggest more bioavailable iron deposition?, Geophys. Res. Lett., 39, L05807, doi:10.1029/2011GL050455, 2012.

Iversen, J. D. and White, B. R.: Saltation threshold on Earth, Mars and Venus, Sedimentology, 29, 111-119, 1982.

Kalivitis, N., Gerasopoulos, E., Vrekoussis, M., Kouvarakis, G., Kubilay, N., Hatzianastassiou, N., Vardavas, I., and Mihalopoulos, N.: Dust transport over the eastern Mediterranean derived from Total Ozone Mapping Spectrometer, Aerosol Robotic Network, and surface measurements, J. Geophys. Res., 112, D03202, doi:10.1029/2006JD007510, 2007.

Kiehl, J., Hack, J., Bonan, G., Boville, B., Breigleb, B., Williamson, D., and Rasch, P.: Description of the NCAR community climate model (ccm3), Tech. rep., National Center for Atmospheric Research Tech Note NCAR/TN-420+STR, NCAR, Boulder, CO, 1996.
Kok, J. F.: A scaling theory for the size distribution of emitted dust aerosols suggests climate models underestimate the size of the global dust cycle, P. Natl. Acad. Sci. USA, 108, 1016-1021, doi:10.1073/pnas.1014798108, 2011a.

Kok, J. F.: Does the size distribution of mineral dust aerosols depend on the wind speed at emission?, Atmos. Chem. Phys., 11, 1014910156, doi:10.5194/acp-11-10149-2011, 2011 b.

Kok, J. F., Parteli, E. J. R., Michaels, T. I., and Karam, D. B.: The physics of wind-blown sand and dust, Reports on Progress in Physics, 75, 106901, doi:10.1088/0034-4885/75/10/106901, 2012.

Konare, A., Zakey, A. S., Solmon, F., Giorgi, F., Rauscher, S., Ibrah, S., and Bi, X.: A regional climate modeling study of the effect of desert dust on the West African monsoon, J. Geophys. Res., 113, D12206, doi:10.1029/2007JD009322, 2008.

Lelieveld, J., Berresheim, H., Borrmann, S., Crutzen, P. J., Dentener, F. J., Fischer, H., Feichter, J., Flatau, P. J., Heland, J., Holzinger, R., Korrmann, R., Lawrence, M. G., Levin, Z., Markowicz, K. M., Mihalopoulos, N., Minikin, A., Ramanathan, V., de Reus, M., Roelofs, G. J., Scheeren, H. A., Sciare, J., Schlager, H., Schultz, M., Siegmund, P., Steil, B., Stephanou, E. G., Stier, P., Traub, M., Warneke, C., Williams, J., and Ziereis, H.: Global Air Pollution Crossroads over the Mediterranean, Science, 298, 794-799, doi:10.1126/science.1075457, 2002.

Levy, R. C., Remer, L. A., Mattoo, S., Vermote, E. F., and Kaufman, Y. J.: Second-generation operational algorithm: Retrieval of aerosol properties over land from inversion of Moderate Resolution Imaging Spectroradiometer spectral reflectance, J. Geophys. Res., 112, D13211, doi:10.1029/2006JD007811, 2007.

Liao, H. and Seinfeld, J. H.: Radiative forcing by mineral dust aerosols: sensitivity to key variables, J. Geophys. Res., 103, 31637-31645, doi:10.1029/1998JD200036, 1998.

Mahowald, N. M., Engelstaedter, S., Luo, C., Sealy, A., Artaxo, P., Benitez-Nelson, C., Bonnet, S., Chen, Y., Chuang, P. Y., Cohen, D. D., Dulac, F., Herut, B., Johansen, A. M., Kubilay, N., Losno, R., Maenhaut,W., Paytan, A., Prospero, J. M., Shank, L. M., and Siefert, R. L.: Atmospheric Iron Deposition: Global Distribution, Variability, and Human Perturbations, Annu. Rev. Mar. Sci., 1, 245-278, doi:10.1146/annurev.marine.010908.163727, 2009.

Malavelle, F., Mallet, M., Pont, V., Liousse, C., and Solmon, F.: Long-term simulations (2001-2006) of biomass burning and mineral dust optical properties over West Africa: comparisons with new satellite retrievals, Atmos. Chem. Phys. Discuss., 11, 28587-28626, doi:10.5194/acpd-11-28587-2011, 2011.

Marticorena, B. and Bergametti, G.: Modeling the atmosphere dust cycle: 1 . Design of a soil-derived dust emission scheme, J. Geophys. Res., 100, 16415-16430, 1995.

Marticorena, B., Bergametti, G., and Aumont, B.: Modeling the atmospheric dust cycle 2. Simulation of Saharan dust sources, J. Geophys. Res., 102, 4387-4404, 1997.

McConnell, C. L., Highwood, E. J., Coe, H., Formenti, P., Anderson, B., Osborne, S., Nava, S., Desboeufs, K., Chen, G., and Harrison, M. A. J.: Seasonal variations of the physical and optical characteristics of Saharan dust: Results from the Dust Outflow and Deposition to the Ocean (DODO) experiment, J. Geophys. Res., 113, D14S05, doi:10.1029/2007JD009606, 2008. 
Miller, R. L., Cakmur, R. V., Perlwitz, J., Geogdzhayev, I. V., Ginoux, P., Koch, D., Kohfeld, K. E., Prigent, C., Ruedy, R., Schmidt, G. A., and Tegen, I.: Mineral dust aerosols in the NASA Goddard Institute for Space Sciences ModelE atmospheric general circulation model, J. Geophys. Res., 111, D06208, doi:10.1029/2005JD005796, 2006.

Mona, L., Amodeo, A., Pandolfi, M., and Pappalardo, G.: Saharan dust intrusions in the Mediterranean area: Three years of Raman lidar measurements, J. Geophys. Res., 111, D16203, doi:10.1029/2005JD006569, 2006.

Moulin, C., Lambert, C. E., Dulac, F., and Dayan, U.: Control of atmospheric export of dust from North Africa by the North Atlantic Oscillation, Nature, 387, 691-694, 1997.

Moulin, C., Lambert, C. E., Dayan, U., Masson, V., Ramonet, M., Bousquet, P., Legrand, M., Balkanski, Y. J., Guellel, W., Marticorena, B., Bergametti, G., and Dulac, F.: Satellite climatology of African dust transport in the Mediterranean atmosphere, J. Geophys. Res., 103, 13137-13144, doi:10.1029/98JD00171, 1998.

Papadimas, C. D., Hatzianastassiou, N., Matsoukas, C., Kanakidou, M., Mihalopoulos, N., and Vardavas, I.: The direct effect of aerosols on solar radiation over the broader Mediterranean basin, Atmos. Chem. Phys., 12, 7165-7185, doi:10.5194/acp-12-71652012, 2012.

Patadia, F., Yang, E.-S., and Christopher, S. A.: Does dust change the clear sky top of atmosphere shortwave flux over high surface reflectance regions?, Geophys. Res. Lett., 36, L15825, doi:10.1029/2009GL039092, 2009.

Qian, Y., Giorgi, F., Huang, Y., Chameides, W., and Luo, C.: Regional simulation of anthropogenic sulfur over East Asia and its sensitivity to model parameters, Tellus B, 53, 171-191, doi:10.1034/j.1600-0889.2001.d01-14.x, 2001.

Reid, J. S., Reid, E. A., Walker, A., Piketh, S., Cliff, S., Mandoos, A. A., Tsay, C. S., and Eck, T. F.: Dynamics of southwest Asian dust particle size characteristics with implications for global dust research, J. Geophys. Res., 113, D14212, doi:10.1029/2007JD009752, 2008.

Santese, M., Perrone, M. R., Zakey, A. S., De Tomasi, F., and Giorgi, F.: Modeling of Saharan dust outbreaks over the Mediterranean by RegCM3: case studies, Atmos. Chem. Phys., 10, 133 156, doi:10.5194/acp-10-133-2010, 2010.

Shao, Y.: A model for mineral dust emission, J. Geophys. Res., 106, 20239-20254, doi:10.1029/2001JD900171, 2001.

Shao, Y.: Physics and Modelling of Wind Erosion, 2nd Edn., Springer, Heidelberg, 2008.

Shao, Y., Raupach, M. R., and Findlater, P. A.: Effect of Saltation Bombardment on the Entrainment of Dust by Wind, J. Geophys. Res., 98, 12719-12726,, 1993.

Shao, Y., Ishizuka, M., Mikami, M., and Leys, J. F.: Parameterization of size-resolved dust emission and validation with measurements, J. Geophys. Res., 116, D08203, doi:10.1029/2010JD014527, 2011.

Slingo, A., Ackerman, T. P., Allan, R. P., Kassianov, E. I., McFarlane, S. A., Robinson, G. J., Barnard, J. C., Miller, M. A., Harries, J. E., Russell, J. E., and Dewitte, S.: Observations of the impact of a major Saharan dust storm on the atmospheric radiation balance, Geophys. Res. Lett., 33, L24817, doi:10.1029/2006GL027869, 2006.
Sokolik, I. N., Winker, D. M., Bergametti, G., Gillette, A., Carmichael, G., Kaufman, Y. J., Gomes, L., Schuetz, L., and Pennear, J. E.: Introduction to special section: Outstanding problems in quantifying the radiative impacts of mineral dust, J. Geophys. Res., 106, 18015-18027, doi:10.1029/2000JD900498, 2001.

Solmon, F., Giorgi, F., and Liousse, C.: Aerosol modelling for regional climate studies: application to anthropogenic particles and evaluation over a European/African domain, Tellus B, 58, 51-72, doi:10.1111/j.1600-0889.2005.00155.x, 2006.

Solmon, F., Mallet, M., Elguindi, N., Giorgi, F., Zakey, A., and Konaré, A.: Dust aerosol impact on regional precipitation over western Africa, mechanisms and sensitivity to absorption properties, Geophys. Res. Lett., 35, L24705, doi:10.1029/2008GL035900, 2008.

Solmon, F., Elguindi, N., and Mallet, M.: Radiative and climatic effects of dust over West Africa, as simulated by a regional climate model, Clim. Res., 52, 97-113, doi:10.3354/cr01039, 2012.

Somot, S., Sevault, F., Déqué, M., and Crépon, M.: 21st century climate change scenario for the Mediterranean using a coupled atmosphere-ocean regional climate model, Global Planet. Change, 63, 112-126, doi:10.1016/j.gloplacha.2007.10.003, 2008.

Sullivan, R. C., Guazzotti, S. A., Sodeman, D. A., and Prather, K. A.: Direct o bservations of the atmospheric processing of Asian mineral dust, Atmos. Chem. Phys., 7, 1213-1236, doi:10.5194/acp-7-1213-2007, 2007.

Sundqvist, H., Berge, E., and Kristjansson, J. E.: The effects of domain choice on summer precipitation simulation and sensitivity in a regional climate model, J. Climate, 11, 2698-2712, 1989.

Sylla, M. B., Coppola, E., Mariotti, L., Giorgi, F., Ruti, P. M., Dell'Aquila, A., and Bi, X.: Multiyear simulation of the African climate using a regional climate model (RegCM3) with the high resolution ERA-interim reanalysis, Clim. Dynam., 35, 231-247, 2009.

Sylla, M. B., Dell'Aquila, A., Ruti, P. M., and Giorgi, F.: Simulation of the intraseasonal and the interannual variability of rainfall over West Africa with RegCM3 during the monsoon period, Roy. Meteorol. Soc., 30, 1865-1883, doi:10.1002/joc.2029, 2010.

Tanré, D., Kaufman, Y. J., Herman, M., and Mattoo, S.: Remote sensing of aerosol properties over oceans using the MODIS/EOS spectral radiances, J. Geophys. Res., 102, 16971-16988, 1997.

Taylor, K. E.: Summarizing multiple aspects of model performance in a single diagram, J. Geophys. Res., 106, 7183-7192, doi:10.1029/2000JD900719, 2001.

Tegen, I. and Lacis, A.: Modeling of particle size distribution and its influence on the radiative properties of mineral dust aerosol, J. Geophys. Res., 101, 19237-19244, doi:10.1029/95JD03610, 1996.

Todd, M. C., Karam, D. B., Cavazos, C., Bouet, C., Heinold, B., Baldasano, J. M., Cautenet, G., Koren, I., Perez, C., Solmon, F., Tegen, I., Tulet, P., Washington, R., and Zakey, A.: Quantifying uncertainty in estimates of mineral dust flux: An intercomparison of model performance over the Bodélé Depression, northern Chad, J. Geophys. Res., 113, D24107, doi:10.1029/2008JD010476, 2008.

Tummon, F., Solmon, F., Liousse, C., and Tadross, M.: Simulation of the direct and semidirect aerosol effects on the southern Africa regional climate during the biomass burning season, J. Geophys. Res., 115, D19206, doi:10.1029/2009JD013738, 2010. 
Uno, I., Wang, Z., Chiba, M., Chun, Y. S., Gong, S. L., Hara, Y., Jung, E., Lee, S.-S., Liu, M., Mikami, M., Music, S., Nickovic, S., Satake, S., Shao, Y., Song, Z., Sugimoto, N., Tanaka, T., and Westphal, D. L.: Dust model intercomparison (DMIP) study over Asia: Overview, J. Geophys. Res., 111, D12213, doi:10.1029/2005JD006575, 2006.

Vaughan, M., Young, S., Winker, D., Powell, K., Omar, A., Liu, Z., Hu, Y., and Hostetler, C.: Fully automated analysis of space-based lidar data: an overview of the CALIPSO retrieval algorithms and data products, Proc. SPIE, 5575, 16-30, doi:10.1117/12.572024, 2004.

Wang, H., Shi, G., Li, S., Li, W., Wang, B., and Huang, Y.: The impacts of optical properties on radiative forcing due to dust aerosol, Adv. Atmos. Sci., 23, 431-441, doi:10.1007/s00376006-0431-5, 2006.

Winker, D., Vaughan, M., Omar, A., Hu, Y., Powell, K., Liu, Z., Hunt, W. H., and Young, S. A.: Overview of the CALIPSO Mission and CALIOP Data Processing Algorithms, J. Atmos. Ocean. Tech., 26, 2310-2323, doi:10.1175/2009JTECHA1281.1, 2009.

Woodage, M. J., Slingo, A., Woodward, S., and Comer, R. E.: Simulations of Desert Dust and Biomass Burning Aerosols with a High-Resolution Atmospheric GCM, J. Climate, 23, 1636-1659, doi:10.1175/2009JCLI2994.1, 2010.

Yan, L., Liu, X., Yang, P., Yin, Z.-Y., and North, G. R.: Study of the Impact of Summer Monsoon Circulation on Spatial Distribution of Aerosols in East Asia Based on Numerical Simulations, J. Appl. Meteorol. Clim., 50, 2270-2282, doi:10.1175/2011JAMCD-11-06.1, 2011.
Yang, E.-S., Gupta, P., and Christopher, S. A.: Net radiative effect of dust aerosols from satellite measurements over Sahara, Geophys. Res. Lett., 36, L18812, doi:10.1029/2009GL039801, 2009.

Yue, X., Liao, H., Wang, H. J., Li, S. L., and Tang, J. P.: Role of sea surface temperature responses in simulation of the climatic effect of mineral dust aerosol, Atmos. Chem. Phys., 11, 60496062, doi:10.5194/acp-11-6049-2011, 2011.

Zakey, A. S., Solmon, F., and Giorgi, F.: Implementation and testing of a desert dust module in a regional climate model, Atmos. Chem. Phys., 6, 4687-4704, doi:10.5194/acp-6-4687-2006, 2006.

Zakey, A. S., Giorgi, F., and Bi, X.: Modeling of sea salt in a regional climate model: Fluxes and radiative forcing, J. Geophys. Res., 113, D14221, doi:10.1029/2007JD009209, 2008.

Zender, C. S., Bian, H., and Newman, D.: Mineral Dust Entrainment and Deposition (DEAD) model: Description and 1990s dust climatology, J. Geophys. Res., 108, 4416, doi:10.1029/2002JD002775, 2003.

Zhang, D. F., Zakey, A. S., Gao, X. J., Giorgi, F., and Solmon, F.: Simulation of dust aerosol and its regional feedbacks over East Asia using a regional climate model, Atmos. Chem. Phys., 9, 1095-1110, doi:10.5194/acp-9-1095-2009, 2009. 